\title{
Insights into the Bioprospecting of the Endophytic Fungi of the Medicinal Plant Palicourea rigida Kunth (Rubiaceae): Detailed Biological Activities
}

\author{
Igor Romeiro dos Santos ${ }^{1}$, Ahmed M. Abdel-Azeem ${ }^{2, *}$, , Marwa T. Mohesien ${ }^{3}$, Magdalena Piekutowska ${ }^{4}(\mathbb{D}$, \\ Donia H. Sheir ${ }^{5}{ }^{-}$, Lucas Leonardo da Silva ${ }^{1}{ }^{1}$, Camila da Silva Castro ${ }^{1}$, Daniel Diego Costa Carvalho ${ }^{6}$, \\ Jadson Diogo Pereira Bezerra ${ }^{7}$, Hosam A. Saad ${ }^{8}\left(\mathbb{D}\right.$, Leonardo Luiz Borges ${ }^{1}$ and Solange Xavier-Santos ${ }^{2, *(1)}$ \\ check for \\ updates \\ Citation: dos Santos, I.R.; \\ Abdel-Azeem, A.M.; Mohesien, M.T.; \\ Piekutowska, M.; Sheir, D.H.; da \\ Silva, L.L.; da Silva Castro, C.; \\ Carvalho, D.D.C.; Bezerra, J.D.P.; \\ Saad, H.A.; et al. Insights into the \\ Bioprospecting of the Endophytic \\ 1 Basic, Applied and Scientific Divulgation Mycolgy Laboratory (FungiLab), Central Campus, \\ State University of Goiás, Anápolis 75132-903, GO, Brazil; igor.santos@aluno.ueg.br (I.R.d.S.); \\ lucasleo.bio@gmail.com (L.L.d.S.); camila.castro@aluno.ueg.br (C.d.S.C.); leonardo.borges@ueg.br (L.L.B.) \\ 2 Botany and Microbiology Department, Faculty of Science, Suez Canal University, Ismailia 41522, Egypt \\ 3 Botany and Microbiology Department, Faculty of Science, Damietta University, New Damietta 34511, Egypt; \\ marwabotany@yahoo.com \\ 4 Department of Geoecology and Geoinformation, Institute of Biology and Earth Sciences, \\ Pomeranian University in Słupsk, Partyzantów 27, 76-200 Słupsk, Poland; \\ magdalena.piekutowska@apsl.edu.pl \\ 5 National Research Centre, Chemistry of Natural and Microbial Products Department, \\ Pharmaceutical Industries Division, Giza 12622, Egypt; donia_sheir@yahoo.com \\ 6 Phytopathology Laboratory, Southeast Campus, State University of Goiás, Ipameri 75780-000, GO, Brazil; \\ daniel.carvalho@ueg.br \\ 7 Mycology Sector, Department of Biosciences and Technology, Institute of Tropical Pathology and \\ Public Health, Federal University of Goiás, Goiânia 74690-900, GO, Brazil; jadsonbezerra@ufg.br \\ 8 Department of Chemistry, College of Science, Taif University, P.O. Box 11099, Taif 21944, Saudi Arabia; \\ h.saad@tu.edu.sa \\ * Correspondence: Ahmed_abdelazeem@science.suez.edu.eg (A.M.A.-A.); solange.xavier@ueg.br (S.X.-S.)
} Fungi of the Medicinal Plant Palicourea rigida Kunth (Rubiaceae): Detailed Biological Activities. J. Fungi 2021, 7, 689. https://doi.org/ 10.3390/jof7090689

Academic Editors: Leire Molinero-Ruiz and Ofir Degani

Received: 27 July 2021

Accepted: 23 August 2021

Published: 25 August 2021

Publisher's Note: MDPI stays neutral with regard to jurisdictional claims in published maps and institutional affiliations.

Copyright: (c) 2021 by the authors. Licensee MDPI, Basel, Switzerland. This article is an open access article distributed under the terms and conditions of the Creative Commons Attribution (CC BY) license (https:// creativecommons.org/licenses/by/ $4.0 /)$.
Abstract: A multitude of plants from the Brazilian savanna are known for their medicinal properties. Many plants contain endophytic fungi, which lead to the production of bioactive compounds by both the fungi and their hosts. This study investigated the bioprospecting of endophytic fungi recovered from the leaves of Palicourea rigida, a native medicinal plant of the Brazilian savanna. Four fungal taxa (Colletotrichum sp. SXS649, Pestalotiopsis sp. SXS650, the order Botryosphaeriales SXS651, and Diaporthe sp. SXS652) were recovered. The phenolic, flavonoid, extracellular degrading enzymes (amylase, cellulase, protease, and tannase) and antioxidant activity of these taxa were determined. Evaluation of the antimicrobial activity showed that the Botryosphaeriales SXS651 extract displays a minimum inhibitory concentration (MIC) of $23.20 \mathrm{mg} \mathrm{mL}^{-1}$ against Staphylococcus epidermidis and Pseudomonas aeruginosa, and the Diaporthe sp. SXS652 extract exhibited an MIC of $27.00 \mathrm{mg} \mathrm{mL}^{-1}$ against Escherichia coli. The Colletotrichum sp. SXS649 isolate inhibited tumors in potato discs by $69 \%$ at a concentration of $9.70 \mathrm{mg} \mathrm{mL}^{-1}$. All isolates had potential bioremediation criteria against soil contaminated with soybean oil, as proved by a high percentage of germination of Lactuca sativa and a reduction in phytotoxicity. Furthermore, the taxa under investigation demonstrated antagonistic action to phytopathogenic fungi, namely, Aspergillus niger, Inonotus rickii, Pestalotiopsis mangiferae, and Coniophora puteana, with an inhibition range between $34.2 \%$ and $76.9 \%$. The preliminary toxicity assessment showed that all isolates possessed an LC50 of less than $100 \mathrm{mg} \mathrm{mL}^{-1}$ to the microcrustacean Artemia salina. These results indicate that the endophytic fungi of the Brazilian savanna are promising candidates for biotechnological and industrial applications and, in agricultural applications, for the biological control of phytopathogenic fungi.

Keywords: endophytic fungi; medicinal plants; bioprospecting; secondary metabolites; biotechnological potential; natural products 


\section{Introduction}

The Brazilian savanna is the largest region of tropical savanna vegetation in the world and one of the main biodiversity hotspots, with many endemics and some threatened species [1,2]. A large portion of the savanna's biodiversity lies in its medicinal plants, which are used in folk medicine or religious rituals [3]. Many of these plants have been processed by the pharmaceutical industry to obtain bioactive substances or used as herbal medicines [4]. Natural products containing secondary metabolites are important indicators of plant species bioactivity [5]. In addition to plants, endophytic microorganisms have also been explored to obtain these compounds [6]. Several plant tissues harbor endophytic microorganisms that protect against pests and pathogens, aiding plant growth, providing resistance to stress, and producing enzymes and other metabolites [7]. In turn, endophytic fungi receive nutrients and protection from the host [8]. The worldwide exploration of medicinal plants has led to a loss of diversity, and this reinforces the need for the investigation and discovery of different sources of bioactive compounds [9]. Fungi are valuable sources of natural products with diverse potentials $[10,11]$.

Bioprospecting research in endophytes still needs much attention because few products from it are available in the pharmaceutical market [9,12]. The main biological activities of endophytic fungi are antimicrobial [13,14], antitumor [15,16], enzymatic [17], antioxidant [18-20], and insecticidal [20,21]. Several natural products of endophytic fungi isolated from medicinal plants in the Brazilian savanna are reported in the literature. The antimicrobial and anticancer activities of endophytes of Stryphnodendron adstringens (Mart.) [22] and Baccharis trimera (Less.) DC. Ref. [23] have been highlighted, as have the antioxidant and anticholinesterase activities of endophytic fungi of Casearia sylvestris Sw. [24].

Therefore, the importance of promoting studies to contribute to the knowledge and bioprospecting of endophytic fungi associated with medicinal species from the Brazilian savanna becomes evident, as previous studies, although scarce, present relevant results for biotechnology [22]. Microbial biotechnology has promoted new perspectives for applications of beneficial endophytic microbes for industry, agriculture and medicine, attracting the attention of the scientific community due to its adaptability in plants to extreme abiotic conditions [6].

In this perspective, Palicourea rigida Kunth (Rubiaceae) is a medicinal plant native to the savanna and used in folk medicine for the treatment of urinary disorders and disorders of the female reproductive system $[25,26]$. It is also used as a diuretic, hypotensive, healer, and treatment for stomach and kidney pain and for coughs [27]. However, the endophytic mycobiota of this species have not been reported yet, including their bioactive properties. This work aimed at promoting the bioprospecting of the biological activity of endophytic fungi isolated from P. rigida leaves in terms of their enzymatic, antioxidant, antimicrobial, antitumor, bioremediative, antagonistic, and toxicity potential.

\section{Materials and Methods}

\subsection{Study Area and Sampling}

P. rigida plants were collected from the UEG Ecological Reserve (REC-UEG), a fragment of the savanna sensu stricto located on the Central Campus of the State University of Goiás, Anápolis, Goiás $\left(16^{\circ} 23^{\prime} 40^{\prime \prime} \mathrm{S}\right.$ e $37^{\circ} 57^{\prime} 32^{\prime \prime} \mathrm{W}$ ) (Figure 1). The area is characterized by the savanna sensu stricto phytophysiognomies, dry forest, and gallery forest [28]. The climate of the region is of the Cwb type (tropical of altitude, with dry winters and hot, humid summers) according to the Köppen classification [29].

Three healthy specimens of $P$. rigida from the savanna sensu stricto at the georeferenced points were selected: (1) $16^{\circ} 22^{\prime} 53^{\prime \prime} \mathrm{S}$ and $48^{\circ} 56^{\prime} 39^{\prime \prime} \mathrm{W}$, (2) $16^{\circ} 22^{\prime} 43^{\prime \prime} \mathrm{S}$ and $48^{\circ} 56^{\prime} 34^{\prime \prime} \mathrm{W}$, and (3) $16^{\circ} 22^{\prime} 14^{\prime \prime} \mathrm{S}$ and $48^{\circ} 56^{\prime} 30^{\prime \prime} \mathrm{W}$. Samples were collected in sterilized polyethylene bags and transferred to the laboratory, where they were subsequently plated out. Samples were collected with the permission of the UEG Ecological Reserve (REC-UEG) for scientific purposes, and no endangered species were involved in the study. A herbarium sample 
was deposited in the Herbarium of the State University of Goiás (HUEG), under accession number HUEG 13846.

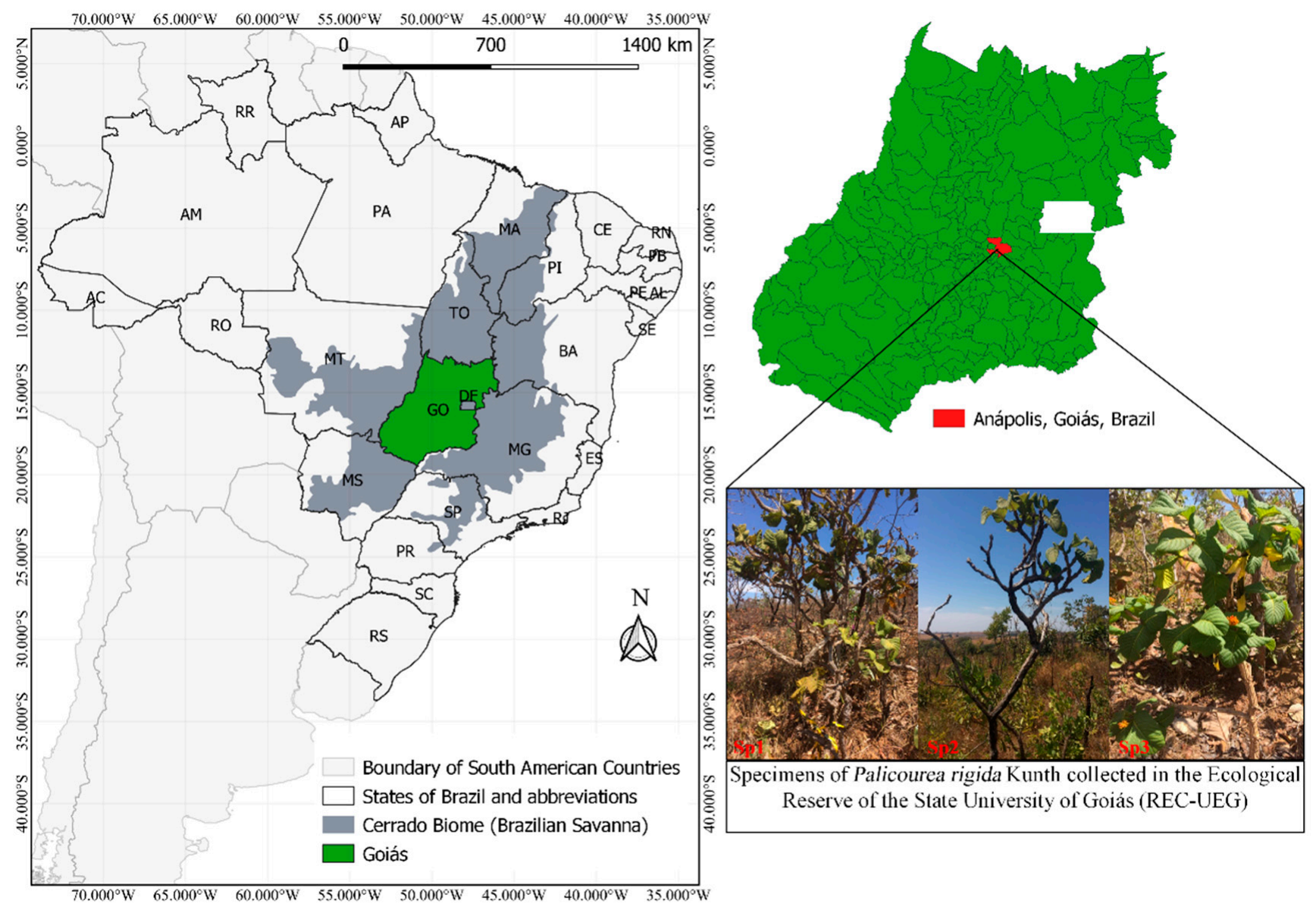

Figure 1. Geographic location of the UEG Ecological Reserve (REC-UEG), Anápolis, Goiás, Brazil and specimens of Palicourea rigida sampled.

\subsection{Isolation of Endophytic Mycobiota}

Pieces of leaves were washed in running water to remove dust residues, immersed in $70 \%$ ethanol for $1 \mathrm{~min}$, transferred to sodium hypochlorite solution ( $2 \%$ active chlorine) for $3 \mathrm{~min}$, and again immersed in $70 \%$ ethanol for $30 \mathrm{~s}$, followed by immersion twice in sterile distilled water. Fragments of approximately 3 to $5 \mathrm{~mm}^{2}$ were cut with the aid of scissors [30]. The fragments were transferred to potato-dextrose-agar (PDA) plates supplemented with the antibiotic chloramphenicol $\left(100 \mu \mathrm{g} \mathrm{mL} \mathrm{m}^{-1}\right)$ to inhibit bacterial growth. Plates were incubated at $27 \pm 2{ }^{\circ} \mathrm{C}$ for up to 60 days and monitored weekly. Twelve endophytic fungi were isolated.

\subsection{Phenotypic Identification}

Identification of the recovered endophytic fungal isolates was conducted based on phenotypic means with the relevant identification keys [31-34]. For Colletotrichum recovered colonies were grown on PDA at $27^{\circ} \mathrm{C}$ for morphological analysis. Taxonomic criteria include color of colony according to Raynor [35], texture and colony growth rate (diameter) were examined after 7 and 10 days. Conidia from the conidiomata in culture were mounted in lactic acid and the length and width measured for 50 randomly selected conidia with the range and mean calculated. For Pestalotiopsis, fungus was grown on PDA. Cultures were incubated at $27^{\circ} \mathrm{C}$ in continuous light, and cultural morphology was examined after 7 days. Colony color was defined according to reported method [35]. Spore size was determined by measuring the length and width of 50 arbitrarily selected conidia from a conidial 
suspension of each colony that was prepared in sterile distilled water (SDW). The isolates were identified initially by comparing morphological and cultural characteristics (i.e., size of conidia, color and length of median cells, thickness and length of apical appendages, and length of basal appendage).

Morphological characterization of Diaporthe was based on sporulating pycnidia from inoculated alfalfa stems placed on $1.5 \%$ water agar (WA). Whenever possible, 40-50 measurements were made of the structures mounted in $5 \% \mathrm{KOH}$. For determination of colony characteristics, PDA as inoculating medium was used at $27^{\circ} \mathrm{C}$ in the dark. Phenotypic criteria of colony included diameters at intervals of $24 \mathrm{~h}$ for 1 week and used to calculate the growth rate of three replicates. After 1 week, colony size and color of the colonies and zonation were recorded [35].

Based on phenotypic identification, four taxa coded from SXS649to SXS652 showed vigorous growth and were selected for more bioprospecting of their biological activity. Cultures of these isolates were preserved according to [36] and deposited in the culture collection of the Basic, Applied Mycology, and Scientific Divulgation Laboratory at UEG (FungiLab) in Brazil and at Suez Canal University Fungarium (SCUF) (http:/ / www.wfcc. info/ccinfo/index.php/collection/by_id/1180/, accessed on 20 August 2021) in Egypt under accession numbers SCFU0001891 to SCUF0001894. Representative endophytic isolates were also deposited in the working collection of Jadson D. P. Bezerra (Fungi Culture Collection, Federal University of Goiás [FCCUFG] at the Institute of Tropical Pathology and Public Health, Federal University of Goiás, Goiânia, Brazil.

\subsection{Extraction of Active Metabolites}

The taxa under investigation were grown on PDA plates for 7 days and transferred to Erlenmeyer flasks $(500 \mathrm{~mL})$ containing $300 \mathrm{~mL}$ of Czapek-Dox broth $\left(\mathrm{NaNO}_{3}, 3 \mathrm{~g} ; \mathrm{K}_{2} \mathrm{HPO}_{3}\right.$, $1 \mathrm{~g} ; \mathrm{MgSO}_{4} \cdot 7 \mathrm{H}_{2} \mathrm{O}, 0.5 \mathrm{~g} ; \mathrm{KCl}, 0.5 \mathrm{~g} ; \mathrm{FeSO}_{4}, 0.01 \mathrm{~g}$; sucrose, $30 \mathrm{~g}$; distilled water, $1000 \mathrm{~mL}$ ) according to the method of Bagheri et al. [37]. Cultures were incubated for 30 days at $27^{\circ} \mathrm{C}$ on a rotary shaker at $150 \mathrm{rpm}$. The fermentation broth of each taxon was filtered; the filtrate so obtained was stored at $10^{\circ} \mathrm{C}$ and used as crude fungal extract for different assay procedure.

\subsection{Determination of Solids Content}

To determine the solids content of each fungal extract, a 1-mL aliquot was placed on a balance with a halogen heating element (Ohaus-MB35) and subjected to $105^{\circ} \mathrm{C}$ for 5 to $10 \mathrm{~min}$. The result was expressed as the average of three determinations, in percentages, thus obtaining the solids content by difference ( $\%$ volatile content $-100=\%$ solids content). The total concentrations of the fungal extract are shown in Table 1, as well as the four standardized concentrations used for the evaluation of the antioxidant, antimicrobial, antitumor, and toxicity activities.

Table 1. Total concentration of solids content of fungal extracts and standardization of concentrations to assess antioxidant, antimicrobial, antitumor and toxicity activities.

\begin{tabular}{cccccc}
\hline \multirow{2}{*}{ Fungal Extract } & \multirow{2}{*}{ Total Solids Content (\%) } & \multicolumn{3}{c}{ Concentration of Fungal Extract Used in Assays (mg $\mathbf{~ m L}^{-\mathbf{1})}$} \\
\cline { 3 - 6 } & & Concentration 1 & Concentration 2 & Concentration 3 & Concentration 4 \\
\hline SXS649 & 0.97 & 9.70 & 4.85 & 2.42 & 1.21 \\
SXS650 & 2.52 & 25.20 & 12.60 & 6.30 & 3.15 \\
SXS651 & 2.32 & 23.20 & 11.60 & 5.80 & 2.90 \\
SXS652 & 2.70 & 27.00 & 13.50 & 6.75 & 3.37 \\
\hline
\end{tabular}

\subsection{Qualitative and Quantitative Screening of Secondary Metabolites}

Qualitative screening of fungal extracts for the presence of saponins, steroids, alkaloids, phenols, and flavonoids was carried out in triplicate, according to previously reported methods of [38-40]. 
Total phenolic content: For the quantitative determination of the total phenolic content, the work of [41] was consulted and adopted. Aliquots of $1 \mathrm{~mL}$ of each fungal extract were placed in test tubes, $0.6 \mathrm{mg} \mathrm{mL}^{-1}$ of gallic acid solution $10 \%$ was added, and the mixture was subsequently transferred to volumetric flasks containing $2 \mathrm{~mL}$ of distilled water. An amount of $100 \mu \mathrm{L}$ of gallic acid solution was added to the test tubes, as well as $2 \mathrm{~mL}$ of Folin-Ciocalteu reagent 3\%. After $5 \mathrm{~min}, 2 \mathrm{~mL}$ of sodium carbonate $\left(\mathrm{Na}_{2} \mathrm{CO}_{3}\right)$ solution $15 \%(\mathrm{~m} / \mathrm{v})$ was added, and the volume was brought up to $900 \mu \mathrm{L}$ with distilled water. After $120 \mathrm{~min}$ in the absence of light, the absorbance was measured at $760 \mathrm{~nm}$ by a digital spectrophotometer (Mod. IL-592-Kazuaki), using gallic acid solution $10 \%$ as the standard, at concentrations of $200,400,600,800$, and $1000 \mu \mathrm{L}$ for construction of the curve. Using the equation for the straight line obtained in the curve of the pattern graph, the total phenol content was calculated, with the results expressed in milligrams of gallic acid in $1 \mathrm{~mL}$ of fungal extract.

Total flavonoid content: For determination of the total flavonoid content, the formula of [42] was applied. Rutin 95\% (3-O-rutinoside-quercetin) $0.1 \mathrm{mg} \mathrm{mL}^{-1}$ was used as a standard solution. Aliquots of $1 \mathrm{~mL}$ of fungal extract were added to $100 \mathrm{~mL}$ of $0.02-\mathrm{M}$ acetic acid methanol solution 99\%. After the solution had rested for $40 \mathrm{~min}$ in the absence of light, the absorbance was measured at $316 \mathrm{~nm}$ by a digital spectrophotometer (Mod. IL-592-Kazuaki). The total flavonoid content was determined using a standard rutin curve at concentrations of $100,200,300,400$, and $500 \mu \mathrm{L}$, and the volume was brought up to $2 \mathrm{~mL}$ with a methanol solution $25 \mathrm{mg} \mathrm{mL}^{-1}$. Using the equation of the straight line obtained in the curve of the standard graph, the total flavonoid content was calculated, with the results expressed in milligrams of rutin in $1 \mathrm{~mL}$ of fungal extract.

HPLC analysis: The extracts were analyzed by high-performance liquid chromatography (HPLC) to separate the components from the samples. Analyses were performed with a Waters model HPLC Alliance chromatograph with an e2695 separation module, 2998 diode array detector (DAD), and Empower 2.0 data-processing system. Chromatographic separations were carried out on a Zorbax Eclipse XDB-C18 reversed-phase column $\left(250 \times 4.6 \mathrm{~mm}^{2}, 5 \mu \mathrm{m}\right)$, using $0.05 \%$ formic acid in HPLC-grade acetonitrile $(\mathrm{pH}=3.45)$ (solvent A) as a mobile phase and $0.05 \%$ formic acid in ultrapure water (Mili-Q) $(\mathrm{pH}=3.15)$ (solvent B) at a flow of $1 \mathrm{~mL}$ min. The following mobile phase gradient was applied: $0 \%$ to $5 \%$ A (0 to $5 \mathrm{~min}$ ); $5 \%$ to $10 \%$ A (5 to $15 \mathrm{~min}$ ); $10 \%$ to $15 \%$ A (15 to $25 \mathrm{~min}$ ), $15 \%$ to $20 \%$ A (25 to $35 \mathrm{~min}$ ), and $15 \mathrm{~min}$ isocratic $20 \%$ A (35 to $50 \mathrm{~min}$ ). The injection volume was $10 \mu \mathrm{L}$ at $35^{\circ} \mathrm{C}$. The mobile phase was previously filtered through a $0.45-\mu \mathrm{m}$ Millex ${ }^{\circledR}$ polyvinylidene fluoride (PVDF) filter (Merck KGaA, Darmstadt, Germany ) and degassed in an ultrasonic bath (USC 1800A, 40 kHz, Unique Group, São Paulo, Brazil).Thus, 1 mL of each fungal extract was diluted in $2 \mathrm{~mL}$ of HPLC-grade methanol and the standards (Sigma Aldrich, Sigma-Aldrich Brasil Ltda. Av. Queirós Filho, 1319 - Vila Humaita, Santo André, Brazil ) were prepared at a concentration of $0.25 \mathrm{mg} \mathrm{mL}^{-1}$ in HPLC-grade methanol. The qualitative presence of caffeic acid, chlorogenic acid, ellagic acid, gallic acid, $p$-coumaric acid, caffeine, catechin, epicatechin and naringenin in each fungal extract was evaluated. The wavelengths used for detection were 254, 327, and $366 \mathrm{~nm}$. The compounds in the extract were identified by comparing the retention times (Tr) and the ultraviolet (UV) absorption spectrum (190 to $400 \mathrm{~nm}$ ) of the peaks obtained. The solutions were previously filtered through a $0.45-\mu \mathrm{m}$ Millex ${ }^{\circledR}$ membrane.

\subsection{Extracellular Degradative Enzymes}

The activity of the amylase, cellulase, protease, lipase, pectinase, and tannase enzymes was assayed by techniques adapted from the work of $[43,44]$. Taxa were cultivated on PDA plates for 5 days, in a bio-oxygen demand (BOD0 incubator), at $27^{\circ} \mathrm{C}$. During this period, a culture disc of $6 \mathrm{~mm}^{2}$ in diameter was inoculated in the center of the Petri dish containing a solid basal minimal medium $\left(\mathrm{NaNO}_{3}, 6 \mathrm{~g} ; \mathrm{KH}_{2} \mathrm{PO}_{4}, 1.5 \mathrm{~g} ; \mathrm{MgSO}_{4} \cdot 7 \mathrm{H}_{2} \mathrm{O}\right.$, $0.5 \mathrm{~g} ; \mathrm{FeSO}_{4}, 0.02 \mathrm{~g} ; \mathrm{ZnSO}_{4}, 0.02 \mathrm{~g}$; agar, $20 \mathrm{~g}$; distilled water, $1000 \mathrm{~mL}$ ), with each of the respective carbon sources, that is, corn starch (5 g) for detection of amylases; $10 \%$ 
carboxymethylcellulose $(5 \mathrm{~g})$ for celluloses; skimmed milk ( $20 \mathrm{~g}$ ) for proteases; Tween 80 $(5 \mathrm{~mL})$ for lipases; pectin $(5 \mathrm{~g})$ for pectinases; and tannic acid $(5 \mathrm{~g})$ for tannases. The plates were incubated at $25^{\circ} \mathrm{C}$ for 5 days. This allowed time for the presence or absence of halo formation around the colony to indicate the enzyme production capacity. To reveal the halo of amylases, lugol solution was used; for cellulases, a $0.1 \%$ congo red solution was used and then the plates were washed with $\mathrm{NaCl}$. For proteases, $1 \%$ methylene blue solution was used; for pectinases, lugol solution was added and washed with water; for lipases, the presence of crystals was verified; and for tannases, a blackened halo was used. The determination of activity was expressed by the enzymatic index (IE) obtained with the formula IE = diameter of the halo/diameter of the colony, according to [45]. Isolates with an IE of 2.00 or greater were those with the highest extracellular enzymatic activity. The tests were carried out in triplicate.

\subsection{Antioxidant Activity}

To verify the antioxidant activity of the fungal extracts, two methods were selected. The first was based on free radical scavenging by using 2,2-diphenyl-1-picryl-hydrazylhydrate (DPPH) and the second on the ferric-reducing ability of plasma (FRAP). The DPPH activity was carried out according to a technique adopted from [46,47]. Each fungal extracts (Table 1) were diluted in $2 \mathrm{~mL}$ of DPPH and $10 \%$ methanol (MeOH) solution $\left(25 \mu \mathrm{g} \mathrm{mL}^{-1}\right)$ to obtaining the values of the solutions $0,200,400,600,800$, and $1000 \mu \mathrm{L} \mathrm{mL}^{-1}$. The mixture was incubated for $30 \mathrm{~min}$ at $37^{\circ} \mathrm{C}$ in the absence of light, and the absorbance was measured at $515 \mathrm{~nm}$ by a digital spectrophotometer (Mod. IL-592-Kazuaki). For comparison with the antioxidant activity of the fungal extract, a standard curve was prepared with a synthetic antioxidant, butylhydroxytoluene (BHT) $\left(25 \mu \mathrm{g} \cdot \mathrm{mL}^{-1}\right)$. The negative control was formed by replacing the sample volume with an equal volume of $\mathrm{MeOH}$, and for the blank, only $\mathrm{MeOH}$ was used. The concentration capable of inhibiting $50 \%$ of the DPPH radical activity (IC50) was calculated by linear regression and expressed as the mean \pm standard deviation, where the $\mathrm{x}$-axis represented the concentration $\left(\mathrm{mg} \mathrm{mL}^{-1}\right)$ and the $y$-axis represented the initial absorbance of the control divided by 2 . The percentage of antioxidant activity was calculated using the equation $\mathrm{AA} \%=[(\mathrm{Ac}-\mathrm{A}) \div \mathrm{Ac}] \times 100$, where $\mathrm{A}$ is the absorbance value of the sample and $A c$ is the absorbance value of the control solution.

The FRAP method evaluates the antioxidant power of iron reduction; it exclusively involves electron transfer reactions in which the reduction of the TPTZ complex (2,4,6-tri $(2-$ pyridyl)-1,3,5-triazine) occurs with $\mathrm{Fe}^{3+}$ to $\mathrm{Fe}^{2+}$ [48]. Each fungal extracts (Table 1) were diluted in $1 \mathrm{~mL}$ distilled water to obtain concentrations of $0,20,40,60,80$, and $100 \mathrm{~mL}-1 \mu \mathrm{L}$. As a standard, a 2.0-mM ferrous sulfate solution was used, from which the analytical curve points were prepared at different concentrations 100, 200, 300 e $400 \mu \mathrm{M}$ ). The FRAP reagent was prepared at the time of analysis by mixing $50 \mathrm{~mL}$ of potassium acetate buffer $(0.3 \mathrm{M}$, $\mathrm{pH}$ 3.6), $5 \mathrm{~mL}$ of TPTZ solution (10 mM TPTZ in $40 \mathrm{mM} \mathrm{HCl}$ ), and $5 \mathrm{~mL}$ of ferric chloride $(20 \mathrm{mM})$ in an aqueous solution. The negative control was formed by replacing the sample volume with an equal volume of distilled water. For the white, only distilled water was used instead of the fungal extract. In a 96-well microplate were added $100 \mu \mathrm{L}$ of the FRAP reagent to each well. The plate was incubated at $37^{\circ} \mathrm{C}$ for $8 \mathrm{~min}$ and then submitted to an absorbance reading at $595 \mathrm{~nm}$ in a microplate spectrophotometer (SpectraMax-M3, Molecular Devices, LLC., 3860 N First Street San Jose, CA, USA). The antioxidant activity was expressed according to the absorbance equivalent to $1000 \mu \mathrm{M}$ of the ferrous sulfate standard, calculated in the equation $y=a x+b$, where $y$ is the absorbance corresponding to $1000 \mu \mathrm{M}$ of ferrous sulfate and ax is the sample dilution $\left(\mathrm{mg} \mathrm{mL}^{-1}\right)$ equivalent to $1000 \mu \mathrm{M}$ of ferrous sulphate.

\subsection{Antimicrobial Activity}

For the evaluation of the antimicrobial activity, the minimum inhibitory concentration (MIC) was determined through microdilution tests in extract according to the Clinical and Laboratory Standard Institute [49], with modifications. Bacterial strains Staphylococcus 
aureus ATCC25923, Staphylococcus epidermidis ATCC12228, Escherichia coli ATCC25312, Pseudomonas aeruginosa ATCC27853, and Klebsiella pneumoniae ATCC700603 and the yeast strains Candida albicans ATCC10231 and Candida tropicalis ATCC13860 were used. Bacterial taxa were inoculated in Mueller Hinton (MH) agar and incubated at $35^{\circ} \mathrm{C}$ for $24 \mathrm{~h}$, and yeast strains were inoculated in Sabouraud agar and incubated at $35^{\circ} \mathrm{C}$ for $24 \mathrm{~h}$.

Bacterial and yeast strains were inoculated singly in a tube containing $4.5 \mathrm{~mL}$ of $0.9 \%$ saline solution until obtaining a turbidity corresponding to 0.5 on the McFarland scale. The solution was diluted 1:100 in saline solution, reaching a concentration of $1106 \mathrm{CFU} \mathrm{mL}^{-1}$ and then inserted into $\mathrm{MH}$ broth and Sabouraud broth. The procedure was performed $20 \mathrm{~min}$ before inoculation into the microplate wells. The fungal extracts were solubilized in MH broth and Sabouraud broth, with serial dilutions in a ratio of 1:1000.

The dilutions of the antibiotic chloramphenicol and the antimycotic miconazole nitrate were prepared according to CLSI recommendations as controls [49]. After preparation of the dilutions, the fungal extracts (Table 1) were diluted in $100 \mu \mathrm{L}$ of MH broth and Sabouraud broth in the microplate wells. As a viability control, $100 \mu \mathrm{L}$ of MH broth and Sabouraud broth were pipetted with the inoculum. As a control for the extracts, $200 \mu \mathrm{L}$ of $\mathrm{MH}$ and Sabouraud broth without inoculum and $200 \mu \mathrm{L}$ of each fungal extract were pipetted. Then, $100 \mu \mathrm{L}$ of each inoculum was deposited in all wells of the plate, except for the wells that were used to control the sterility of the medium and samples. The microplates were sealed and incubated at $35^{\circ} \mathrm{C}$ for $24 \mathrm{~h}$. After the incubation period, $25 \mu \mathrm{L}$ of $0.1 \%$ sodium resazurin was added to all wells. Then the plates were again incubated for $30 \mathrm{~min}$. The absorbance reading was performed by comparing the turbidity of the samples in the wells before adding $0.1 \%$ sodium resazurin and after adding $0.1 \%$ sodium resazurin, considering that the increase in turbidity or opacity in the medium was considered indicative of the growth of microorganisms. This followed the methodology of [50], in which the permanence of the blue color means inhibition of the growth of microorganisms and the pinkish red color means metabolic activity due to the growth of microorganisms. The MIC is defined as the lowest concentration of the compound in $\mathrm{mg} \mathrm{mL}^{-1}$ capable of totally inhibiting bacterial growth visible to the naked eye.

\subsection{Antitumor Activity}

To assess the antitumor activity, Rhizobium radiobacter ATCC4720 was cultivated in tryptone soy agar (TSA) medium for $24 \mathrm{~h}$ and then a bacterial suspension was prepared at a concentration of $1108 \mathrm{CFU} \cdot \mathrm{mL}^{-1}$. It was determined through comparison with the McFarland scale and the dilution of 1:10 in nutrient broth, obtaining a suspension of $1.106 \mathrm{CFU} \cdot \mathrm{mL}^{-1}$, which was incubated for $48 \mathrm{~h}$ at $36^{\circ} \mathrm{C}$ for subsequent incubation of the potato discs [51].

Fresh and peeled medium-sized potatoes (Solanum tuberosum L.) had their surfaces disinfected by immersion in $0.1 \% \mathrm{NaClO}$ for $30 \mathrm{~min}$. Then, potato discs $\left(5 \times 8 \mathrm{~mm}^{2}\right)$ were extracted from the core region, using a metal awl. The potato discs were placed in Petri dishes containing bacteriological agar, and each dish received three discs for each dilution of fungal extract. Each inoculation mixture was prepared with $1900 \mu \mathrm{L}$ of bacterial culture suspension, $0.5 \mathrm{~mL}$ of distilled water and the fungal extracts (Table 1) in $100 \mu \mathrm{L}$ of TSA, thus obtaining the final concentrations of 1000,500 and $250 \mu \mathrm{L}$ of this solution for pipetting onto potato discs. Then, $100 \mu \mathrm{L}$ of each inoculation mixture was inoculated into each potato disc, and the discs were incubated for 20 days at $25^{\circ} \mathrm{C}$. The technique's control discs were made in the same way, except that the fungal extracts were removed. Vincristine $\left(100 \mu \mathrm{g} \mathrm{mL}{ }^{-1}\right)$ was used as a positive control due to its significant effect on tumor inhibition [52]. During this period, the reading was performed $30 \mathrm{~min}$ after the addition of lugol solution $(5 \% \mathrm{I} 2+10 \% \mathrm{KI})$ and tumor counts were performed and compared with the control technique. The results were presented in percentages using the formula 100 - mean tumors found in the sample/mean tumors found in the growth control $\times 100$. Significant activity was indicated by $20 \%$ or more inhibition. 


\subsection{Bioremediative Activity}

To evaluate the potential of fungal extracts for bioremediation of soil contaminated with soybean oil, a soil phytotoxicity reduction test was carried out using lettuce seeds (Lactuca sativa L.) as modified from [53]. Soil samples were collected from the same locations where the host plants $P$. rigida were collected. The soil retention capacity was determined following ISO 17126:2005. By using 300-mL plastic cups perforated in the base, $100 \mathrm{~g}$ of soil sieved in a stainless-steel sieve with 16 openings $\left(1.18 \mathrm{~mm}^{2}\right)$ was weighed and placed in a container with water until saturation for $15 \mathrm{~h}$ to drain the water surplus. During this period, the cups were weighed to obtain the wet soil mass, using the following formula: $\mathrm{C}=\mathrm{mw}-\mathrm{md}$, where $\mathrm{C}$ is the retention capacity $(100 \%), \mathrm{mw}$ is the wet soil mass in grams, and $\mathrm{md}$ is the dry soil mass in grams. Thus, the maximum water retention capacity in $100 \mathrm{~g}$ of soil was found. The concentration of soybean oil considered toxic to L. sativa seeds is $10 \%(10 \mathrm{~mL})$.

Using 300-mL plastic cups perforated in the base, $100 \mathrm{~g}$ of soil was weighed in triplicates. For control 1, soil, water, and 10 lettuce seeds were placed in each cup; for control 2, soil, water, $10 \%$ soybean oil $(10 \mathrm{~mL})$, and 10 lettuce seeds were placed in each cup; and for the soil being treated, $10 \%$ soybean oil $(10 \mathrm{~mL})$ and the value of $\mathrm{C}$ (retention capacity, as obtained previously) of the fungal extract $n=32 \mathrm{~mL}$, were placed in each cup. The preparations were incubated in a germination oven for $144 \mathrm{~h}$ at $25^{\circ} \mathrm{C}$. Afterward, the percentage of germination and length of roots and hypocotyls were verified and were compared with the controls.

\subsection{Antagonistic Activity}

The antagonism evaluation was carried out by dual cultures in plates [54]. Direct inoculation of each recovered endophytic fungus was made against the phytopathogenic fungi isolates, namely, Aspergillus niger SXS635 (black mold fungus in fruits), Inonotus rickii SXS37 (wood rot fungus), Pestalotiopsis mangiferae SXS647 (leaf spot fungus of Mangifera indica), and Coniophora puteana SXS623 (wood rot fungus). Each Petri dish containing PDA medium received two paired 6- $\mathrm{mm}^{2}$ discs equidistantly matched, $1 \mathrm{~cm}^{2}$ from the edge, one disc from the edge of the endophytic fungus colony and the other disc from the edge of the phytopathogenic fungus colony. Then, the plates were incubated at $27^{\circ} \mathrm{C}$ for 14 days. As a control technique (control), the phytopathogenic fungus was inoculated without the presence of endophytic fungi in one pole of the plate.

The competitive interactions between endophytic fungi and phytopathogens were evaluated following the scale of [55]. Three possible types of interactions were expected: A, "deadlock" with mycelial contact; B, distance "deadlock"; and C, endophytic growth on the phytopathogen without initial deadlock, being divided into four subcategories (CA1, CA2, $\mathrm{CB} 1$, and $\mathrm{CB} 2$ ). $\mathrm{CA} 1$ and $\mathrm{CA} 2$ were the partial and complete growth of the endophytic fungus on the phytopathogen after initial deadlock with mycelial contact, and CB1 and CB2 were the partial and complete growth of the endophyte on the phytopathogen after the initial distance deadlock. In addition, to verify the percentage of growth inhibition of the phytopathogen, the area of these compared to the control area was measured, using the formula Percentage of inhibition of phytopathogen growth $(\mathrm{PI} \%)=(\mathrm{Dc}-\mathrm{Dt} / \mathrm{Dc}) \times 100$, where $\mathrm{Dc}$ is the average diameter of the colony of the phytopathogen of the control plates (without antagonist) and $\mathrm{Dt}$ is the average diameter of the colony of the phytopathogen against the antagonist (isolated endophytic) [56].

\subsection{Toxicity}

The toxicity of the fungal extracts was evaluated against Artemia salina Leach. by a modified technique of [57]. Synthetic sea water was prepared by dissolving sea salt $\left(36 \mathrm{~g} \mathrm{~L}^{-1}\right)$ in distilled water, with the addition of a yeast extract $\left(6 \mathrm{mg} \mathrm{L}^{-1}\right)$. The solution was autoclaved at $120^{\circ} \mathrm{C}$ for $15 \mathrm{~min}$. An aliquot of $250 \mathrm{mg}$ of A. salina cysts was incubated for $37 \mathrm{~h}$ in $500 \mathrm{~mL}$ of synthetic marine water, under natural lighting and constant oxygenation at $25^{\circ} \mathrm{C}$. After the incubation period, with the hatching of the cysts and the 
release of the nauplii, they were attracted by a light source, pipetted, and transferred to 96-well polystyrene microplates. Inoculums were standardized on $10 \pm 1$ nauplii for each well containing $100 \mu \mathrm{L}$. The fungal extracts (Table 1) were diluted in $100 \mu \mathrm{L}$ of synthetic seawater, then a further $100 \mu \mathrm{L}$ of synthetic seawater with nauplii was added.

An amount of $10 \mu \mathrm{L}$ of synthetic marine water added to $190 \mu \mathrm{L}$ of sterilized distilled water was used as a control. For lethality, potassium dichromate $\left(\mathrm{K}_{2} \mathrm{Cr}_{2} \mathrm{O}_{7}\right)$ at concentrations of 100, 50, 25, 12.5, and $6.25 \mu \mathrm{g}$ was used [58]. The determination of the LC50 was performed from the count of dead and alive nauplii, after $24 \mathrm{~h}$ of exposure to the extracts, using a stereoscopic optical microscope (Probit dose-response methodology through Statplus version 5.7.8, 2014 professional [Analyst Soft]). Linear regression analysis was obtained from the relationship between the percentage of dead nauplii and the concentration of fungal extracts. The level of toxicity was determined according to [59] and [59]: LC50 < $100 \mathrm{mg} \mathrm{mL}^{-1}$ strong, 100 to $500 \mathrm{mg} \mathrm{mL}^{-1}$ moderate, 500 to $1000 \mathrm{mg} \mathrm{mL}^{-1}$ low, $>1000 \mathrm{mg} \mathrm{mL}^{-1}$ nontoxic.

\subsection{Statistical Analysis}

Results were shown as the mean \pm standard deviation. The analysis of variance (ANOVA) followed by the Tukey test was used to measure the significance level at $5 \%$ in the means of the assessments of bioremediation and antagonism activities using BioEstat 5.3 software.

\section{Results}

The endophytic fungi recovered from $P$. rigida were identified phenotypically as Colletotrichum sp. SXS649- SCFU0001891 (Glomerellaceae: Glomerellales: Sordariomycetes), Pestalotiopsis sp. SXS650- SCFU0001892 (Sporocadaceae: Xylariales: Sordariomycetes), Botryosphaeriales SXS651- SCFU0001893 (Dothideomycetes), and Diaporthe sp. SXS652SCFU0001894 (Diaporthaceae: Diaporthales: Sordariomycetes), all belonging to the phylum Ascomycota. Taxonomically they were belonged to 1 class, 4 orders and three families.

Qualitative screening for secondary metabolites confirmed the presence of phenols and flavonoids in the extracts of all studied isolates, but no detectable content of saponins, steroids and alkaloids. The quantification of the total phenolic compounds and flavonoids showed a content of 210 to $890 \mathrm{mg}$ of a total phenolic equivalent of gallic acid per milliliter of extract and 84 to 374 of a total flavonoid equivalent of rutin per milliliter of extract. The Colletotrichum sp. SXS649 had the highest amount of both metabolites (Table 2). The analysis of the resulting HPLC-DAD chromatograms suggested the presence of compounds in the four fungal extracts (Figure 2); however, none of these compounds were similar to the analyzed patterns caffeic acid, chlorogenic acid, ellagic acid, gallic acid, $p$-coumaric acid, caffeine, catechin, epicatechin and naringenin. Further research is needed to identify the compounds.

Degradative enzymes' activity showed that all isolates had high cellulolytic activity, with an IE between 12.66 and 21.00. Colletotrichum sp. SXS649, Pestalotiopsis sp. SXS650, and Botryosphaeriales SXS651 showed amylolytic activity, with an IE of 3.80, 2.10, and 4.90, respectively. Colletotrichum sp. SXS649 showed proteolytic activity with an IE of 2.53 and tannase activity with an IE of 2.21. No isolate showed lipolytic or pectinolytic activity, with an IE of below 2.00 (Figure 3). 
Table 2. Content of total phenolic compounds and flavonoids in $1 \mathrm{~mL}$ of extract of the endophytic fungi Colletotrichum sp. SXS649, Pestalotiopsis sp. SXS650, Botryosphaeriales SXS651 and Diaporthe sp. SXS652 isolates from $P$. rigida Kunth. Values correspond to the mean of the triplicates \pm standard deviation.

\begin{tabular}{ccc}
\hline Fungal Extract & $\begin{array}{c}\text { Phenolics } \\
\text { (mg of Gallic Acid/1 mL) }\end{array}$ & $\begin{array}{c}\text { Flavonoids } \\
\text { (mg of Rutin/1 mL) }\end{array}$ \\
\hline SXS649 & $890 \pm 12.50$ & $374 \pm 3.00$ \\
SXS650 & $322 \pm 6.55$ & $185 \pm 1.73$ \\
SXS651 & $233 \pm 6.02$ & $84 \pm 2.30$ \\
SXS652 & $210 \pm 4.61$ & $159 \pm 1.52$ \\
\hline
\end{tabular}

Fungal extracts showed a potential antioxidant activity in the DPPH assay, although high concentrations were needed to reach the same capture percentage as the positive control with butylated hydroxytoluene (BHT). The IC50 detected among the isolates is shown in Table 3. Only $0.0118 \mathrm{mg} \mathrm{mL}^{-1}$ of BHT was needed to achieve results similar to those of the extracts. For the percentage of antioxidant activity through free radical capture (AA\%) to reach an average of $65.48 \%$ (the greatest potential), it was necessary to have a concentration of $11.60 \mathrm{mg} \mathrm{mL}^{-1}$ of the extract of the isolate Botryosphaeriales SXS651 e $0.015 \mathrm{mg} \mathrm{mL}^{-1}$ of BHT. For the FRAP assay, extracts from Colletotrichum sp. SXS649, Pestalotiopsis sp. SXS650, and Diaporthe sp. SXS652 presented results corresponding to the sample dilution equivalent to $1000 \mu \mathrm{M}$ of ferrous sulfate. Pestalotiopsis sp. SXS650 and Diaporthe sp. SXS652 showed antioxidant activity at moderate levels with the DPPH and FRAP; Colletotrichum sp. SXS649 showed lower levels of antioxidant activity with the DPPH and FRAP methods; and Botryosphaeriales SXS651 showed lower levels of antioxidant activity with the DPPH method.

Table 3. IC50 values $\left(\mathrm{mg} \mathrm{mL}^{-1}\right)$ of the extracts of the endophytic fungi Colletotrichum sp. SXS649, Pestalotiopsis sp. SXS650, Botryosphaeriales SXS651, and Diaporthe sp. SXS652 isolates from P. rigida Kunth that inhibit DPPH free radicals and reduce iron FRAP.

\begin{tabular}{|c|c|c|c|c|}
\hline Fungal Extract & $\mathrm{IC}_{50} \mathrm{DPPH}^{*}$ & AA $\% * *$ & $\mathrm{IC}_{50}$ FRAP $* * *$ & Concentration to Achieve IC50 $\left(\mathrm{mg} \mathrm{mL}^{-1}\right) * * * *$ \\
\hline SXS649 & $5.6804 \pm 0.38$ & 57.8529 & $8.0917 \pm 0.03$ & 4.85 \\
\hline SXS650 & $22.4748 \pm 1.20$ & 51.2709 & $47.0602 \pm 0.03$ & 25.20 \\
\hline SXS651 & $11.8528 \pm 1.06$ & 65.4832 & 0.00 & 11.60 \\
\hline SXS652 & $27.4803 \pm 0.00$ & 46.3043 & $32.2691 \pm 0.25$ & 27.00 \\
\hline Control (BHT) & $0.0118 \pm 0.00$ & 65.5431 & - & 0.01 \\
\hline
\end{tabular}

Values are the mean of the triplicates \pm standard deviation. ${ }^{*}$ Equivalent to $\mathrm{IC}_{50}$ calculations $\left(\mathrm{mg} \mathrm{mL}^{-1}\right)$ obtained from the graph of absorbance against the concentration for each sample in free radical scavenging. ** Percentage of antioxidant activity calculated by the

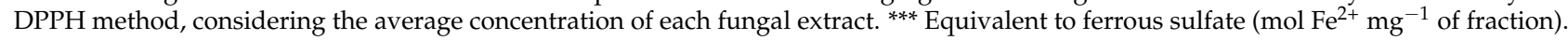
**** Solid content values of fungal extracts to reach $\mathrm{IC}_{50}$ for DPPH and FRAP. 


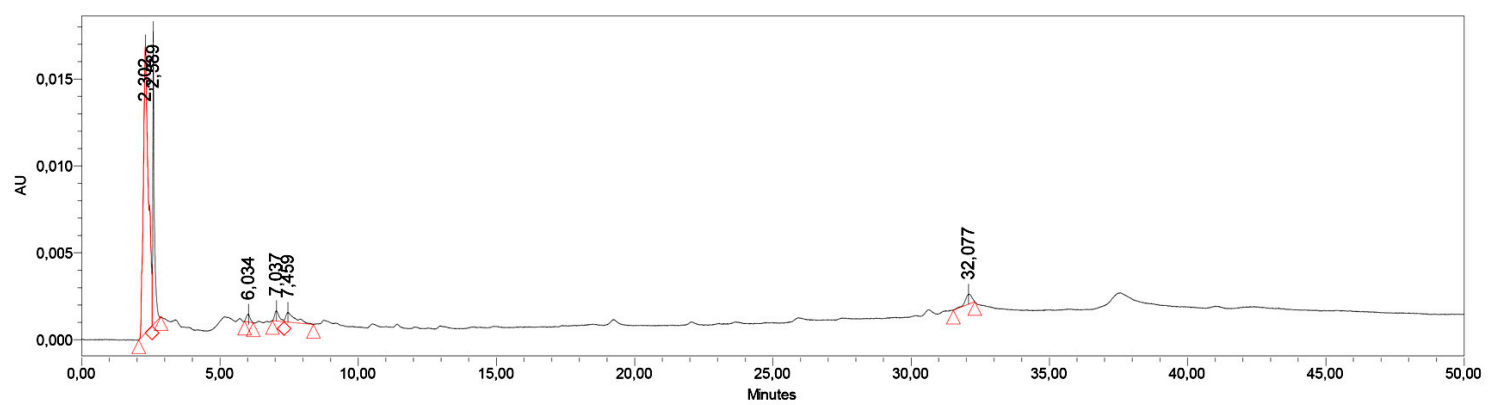

Fungal extract SXS649

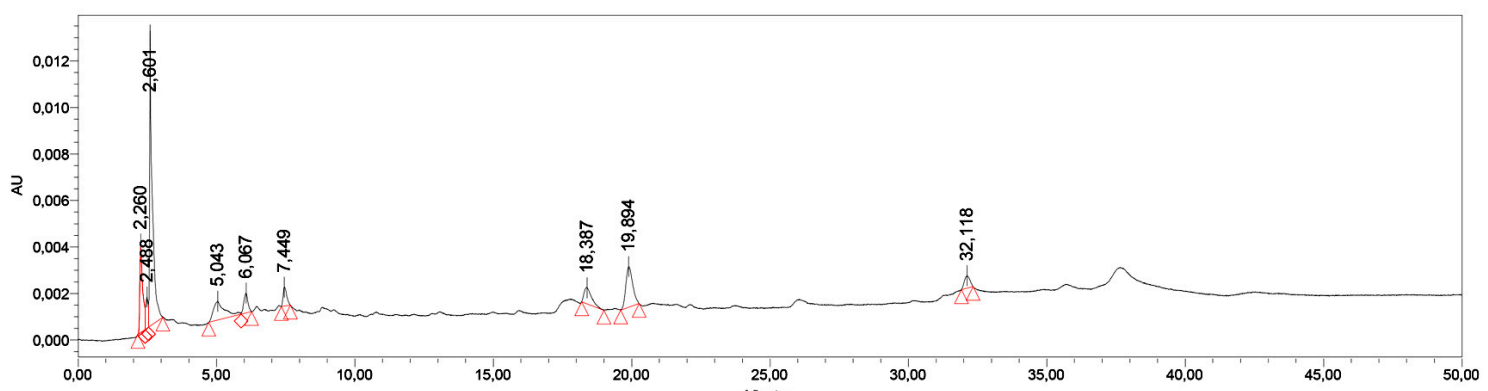

Fungal extract SXS650

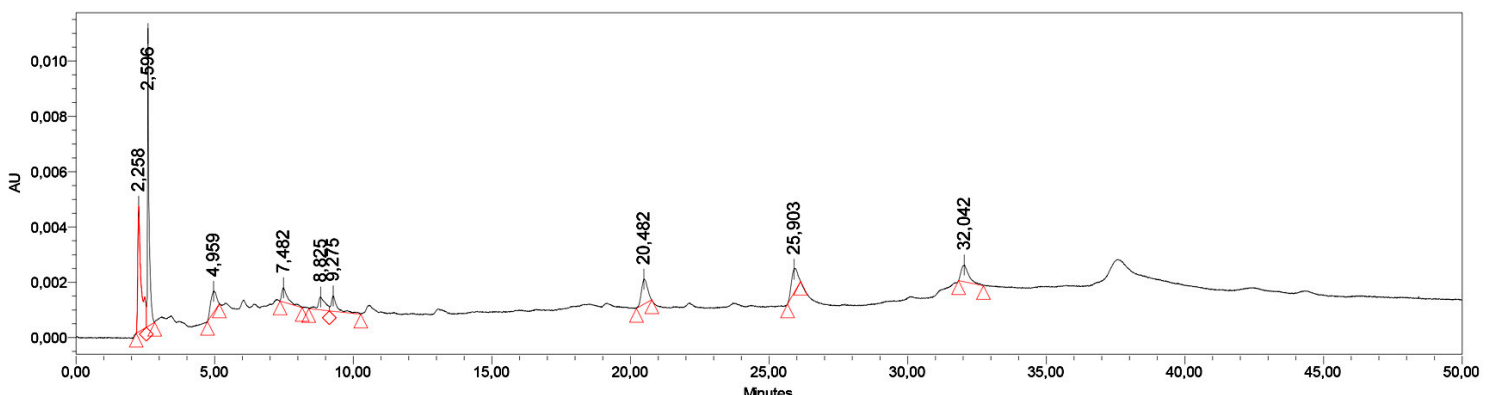

Fungal extract SXS651



Fungal extract SXS652

Figure 2. HPLC chromatograms of extracts of the endophytic fungi Colletotrichum sp. SXS649, Pestalotiopsis sp. SXS650, Botryosphaeriales SXS651, and Diaporthe sp. SXS652 isolates from P. rigida Kunth. Values correspond to the average of 3 repetitions. 


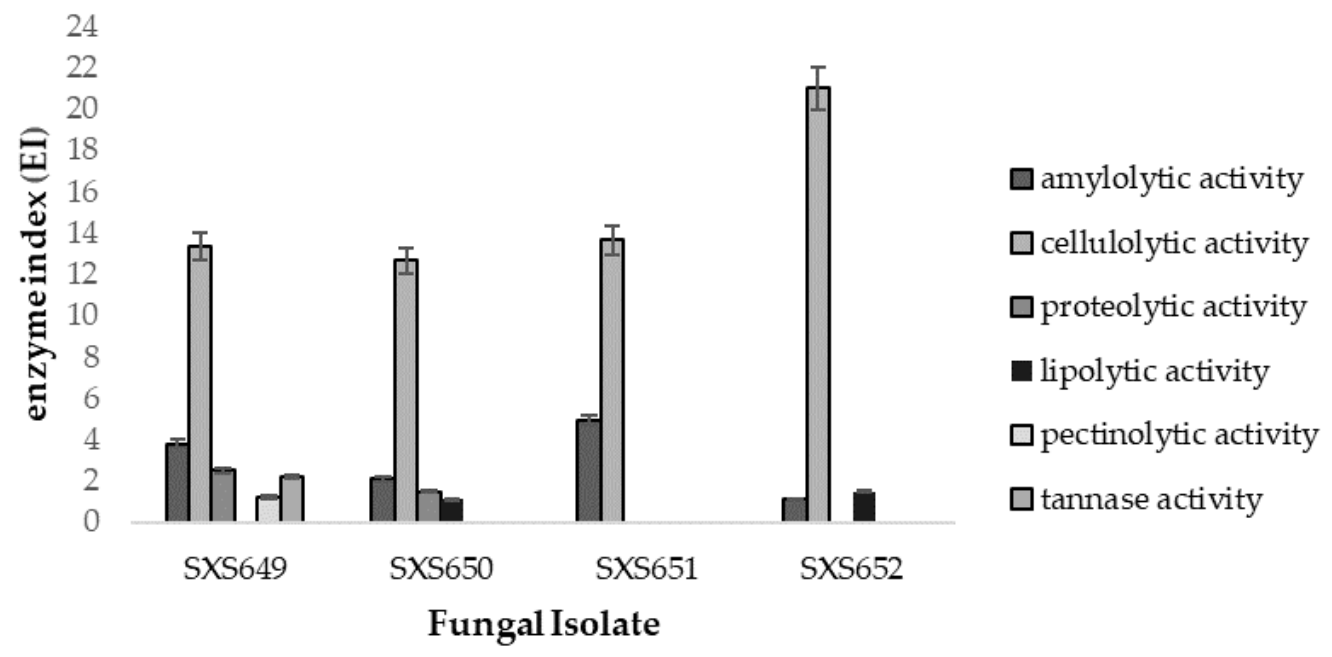

(a)



(b)

Figure 3. Enzymatic profile of the endophytic fungi Colletotrichum sp. SXS649, Pestalotiopsis sp. SXS650, Botryosphaeriales SXS651, and Diaporthe sp. SXS652 isolates from P. rigida Kunth. (a) Enzyme index (IE). Values correspond to the average of 3 repetitions: (b) Cultures in specific media showing the substrate degradation halo as indicative of enzymatic activity.

In verifying the antimicrobial activity, the extract of Botryosphaeriales SXS651 was able to inhibit the bacteria S. epidermidis and P. aeruginosa at a concentration of $23.20 \mathrm{mg} \mathrm{mL}^{-1}$, and the extract of Diaporthe sp. SXS652 showed inhibition of E. coli at a concentration $27.00 \mathrm{mg} \mathrm{mL}^{-1}$. In verifying the antitumor activity, only Colletotrichum sp. SXS649 showed tumor inhibition $(69 \%)$ at a concentration of $9.70 \mathrm{mg} \mathrm{mL}^{-1}$. The other tested concentrations of this isolate showed inhibition of less than $20 \%$ (Figure 4). The extracts from the other fungal isolates did not show antitumor activity and did not inhibit tumor formation by more than $20 \%$.

In verifying the bioremediation capacity of soil contaminated with soybean oil, the maximum water retention capacity in $100 \mathrm{~g}$ of soil was $32 \mathrm{~mL}$. Therefore, this was the 
volume of water or fungal extract added to the soil for the tests. When the soil was contaminated with $10 \%$ soybean oil there was a reduction in the number of germinated seeds (Table 4). In the soil treated with fungal extracts there was an increase in seed germination, with emphasis on treatment with Colletotrichum sp. SXS649, where a germination rate of $72.5 \%$ (32.5\% reduction in phytotoxicity) was verified. This was followed by treatment with Pestalotiopsis sp. SXS650, with a $67.5 \%$ germination rate (27.5\% phytotoxicity reduction); Botryosphaeriales SXS651, with a $65 \%$ germination rate (25\% phytotoxicity reduction), and Diaporthe sp. SXS652, with a $60 \%$ germination rate ( $20 \%$ reduction in phytotoxicity). This same phytotoxicity reducing effect was observed on the root and hypocotyl length.

Table 4. Viability of Lactuca sativa seeds in soil contaminated with $10 \%$ soybean oil and treated with extracts (32 mL) of the endophytic fungi Colletotrichum sp. SXS649, Pestalotiopsis sp. SXS650, Botryosphaeriales SXS651, and Diaporthe sp. SXS652 isolates from $P$. rigida Kunth.

\begin{tabular}{|c|c|c|c|}
\hline Sample Concentrations & $\begin{array}{l}\text { Germination }(\%) \\
\quad(n=240) *\end{array}$ & $\begin{array}{l}\text { Average Length of } \\
\text { Root }\left(\mathrm{mm}^{2}\right)\end{array}$ & $\begin{array}{l}\text { Average Length of the } \\
\text { Hypocotyl }\left(\mathrm{mm}^{2}\right)\end{array}$ \\
\hline $100 \mathrm{~g}$ of soil $+32 \mathrm{~mL}$ of water (Control 1$)$ & $95.00 \pm 5.00^{\mathrm{a}}$ & $23.47 \pm 2.12^{\mathrm{a}}$ & $41.38 \pm 5.47^{\mathrm{a}}$ \\
\hline $100 \mathrm{~g}$ of soil $+10 \%$ soy oil (Control 2$)$ & $40.00 \pm 7.07^{c}$ & $10.38 \pm 2.56^{\mathrm{b}}$ & $18.66 \pm 5.35^{b}$ \\
\hline $100 \mathrm{~g}$ of soil $+10 \%$ soy oil $+32 \mathrm{~mL}$ of SXS649 fungal extract & $72.50 \pm 4.33^{\mathrm{b}}$ & $21.36 \pm 0.81^{\mathrm{a}}$ & $35.90 \pm 1.67^{\mathrm{a}}$ \\
\hline $100 \mathrm{~g}$ of soil $+10 \%$ soy oil $+32 \mathrm{~mL}$ of SXS650 fungal extract & $67.50 \pm 4.33^{\mathrm{b}}$ & $20.86 \pm 2.96^{\mathrm{a}}$ & $34.49 \pm 4.63^{\mathrm{a}}$ \\
\hline $100 \mathrm{~g}$ of soil $+10 \%$ soy oil $+32 \mathrm{~mL}$ of SXS651 fungal extract & $65.00 \pm 5.00^{b}$ & $20.94 \pm 1.64^{\mathrm{a}}$ & $36.62 \pm 1.19^{\mathrm{a}}$ \\
\hline $100 \mathrm{~g}$ of soil $+10 \%$ soy oil $+32 \mathrm{~mL}$ of SXS652 fungal extract & $60.00 \pm 0.00^{b}$ & $22.87 \pm 0.91^{\mathrm{a}}$ & $35.83 \pm 4.12^{\mathrm{a}}$ \\
\hline
\end{tabular}

Values correspond to the mean of the triplicates \pm standard deviation. Values followed by the same letter do not differ statistically by the Tukey test $(p<0.05){ }^{*}(n=$ total number of seeds planted).

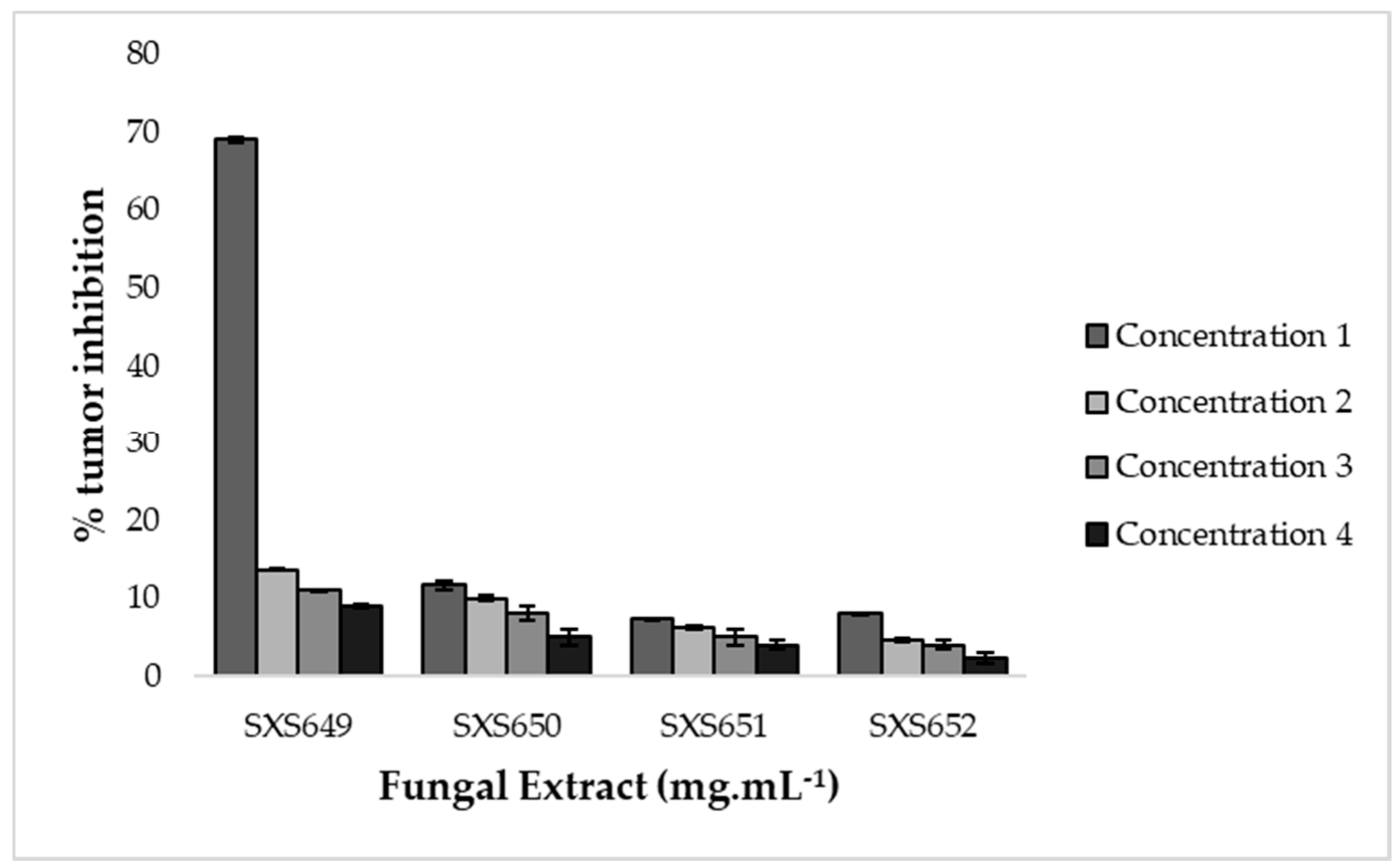

(a)

Figure 4. Cont. 


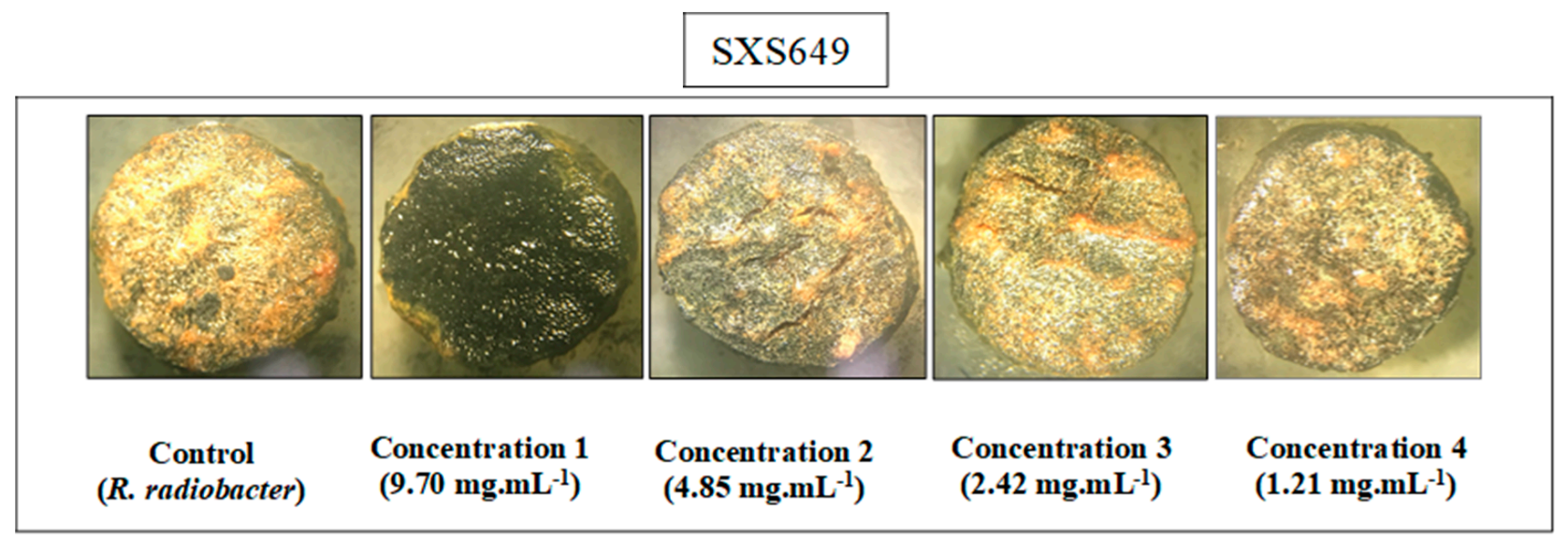

(b)

Figure 4. Antitumor activity in potato discs of extracts of the endophytic fungi Colletotrichum sp. SXS649, Pestalotiopsis sp. SXS650, Botryosphaeriales SXS651, and Diaporthe sp. SXS652 isolates from P. rigida Kunth. (a) Inhibition rate against the concentration of fungal extracts. Values correspond to the average of 3 repetitions; and (b) Potato disc tumors treated with Colletotrichum sp. SXS649.

All isolates showed antagonistic activity against tested phytopathogenic fungi, with a percentage of inhibition (PI\%) of between $34.17 \%$ and $76.93 \%$ (Table 5). All of the endophytes showed an inhibition percentage of greater than $50 \%$ for at least one of the phytopathogenic fungi tested. The three highest percentages of inhibition were against $C$. puteana $(76.93 \%)$, A. niger $(59.25 \%)$, and I. rickii (57.14\%) (Figure 5). In the verification of toxicity, all of the fungal extracts showed high lethality for the microcrustacean $A$. salina (LC50 < $100 \mathrm{mg} \mathrm{mL}^{-1}$ ) (Table 6).

Table 5. Antagonistic action of the endophytic fungi Colletotrichum sp. SXS649, Pestalotiopsis sp. SXS650, Botryosphaeriales SXS651, and Diaporthe sp. SXS652 isolated from P. rigida Kunth against phytopathogenic fungi A. niger SXS635, I. rickii SXS37, P. mangiferae SXS647, and C. puteana SXS623 detected by the plate-pairing method and type of competitive interaction, according to the Badalyan scale (2002).

\begin{tabular}{|c|c|c|c|c|}
\hline Fungal Taxa & A. niger & $\begin{array}{c}\text { Inhibition (\%) } \\
\text { I. rickii }\end{array}$ & P. mangiferae & C. puteana \\
\hline SXS649 & $\begin{array}{c}56.79 \pm 0.89^{a} \\
\text { (B) }\end{array}$ & $\begin{array}{c}50.00 \pm 0.51^{\mathrm{c}} \\
(\mathrm{A})\end{array}$ & $\begin{array}{c}53.16 \pm 1.24 \mathrm{~b} \\
(\mathrm{~A})\end{array}$ & $\begin{array}{c}42.85 \pm 1.22 \mathrm{~b} \\
(\mathrm{~A})\end{array}$ \\
\hline SXS650 & $\begin{array}{c}59.25 \pm 3.60^{\mathrm{a}} \\
\text { (B) }\end{array}$ & $\begin{array}{c}57.14 \pm 1.06^{\mathrm{a}} \\
\text { (A) }\end{array}$ & $\begin{array}{c}48.10 \pm 0.66^{\mathrm{c}} \\
\text { (A) }\end{array}$ & $\begin{array}{c}36.73 \pm 1.08^{c} \\
\text { (B) }\end{array}$ \\
\hline SXS651 & $\begin{array}{c}54.32 \pm 0.87^{\mathrm{a}} \\
\text { (A) }\end{array}$ & $\begin{array}{c}47.14 \pm 1.25^{\mathrm{d}} \\
\text { (A) }\end{array}$ & $\begin{array}{c}56.96 \pm 0.69^{\mathrm{a}} \\
(\mathrm{CA} 1)\end{array}$ & $\begin{array}{c}38.77 \pm 0.89^{\mathrm{c}} \\
(\mathrm{CA} 1)\end{array}$ \\
\hline SXS652 & $\begin{array}{c}50.61 \pm 0.87^{b} \\
\text { (B) }\end{array}$ & $\begin{array}{c}54.28 \pm 1.13^{b} \\
(\mathrm{~A})\end{array}$ & $\begin{array}{c}34.17 \pm 0.81^{d} \\
(A)\end{array}$ & $\begin{array}{c}76.93 \pm 0.81^{\mathrm{a}} \\
(\mathrm{CA} 1)\end{array}$ \\
\hline
\end{tabular}

Values correspond to the mean of the triplicates \pm standard deviation. Values with the same lowercase letter do not differ statistically by the Tukey test $(p<0.05)$. (A) "Deadlock" with mycelial contact; (B) distance "deadlock"; (CA1) partial endophytic growth on the phytopathogen after initial deadlock with mycelial contact. 


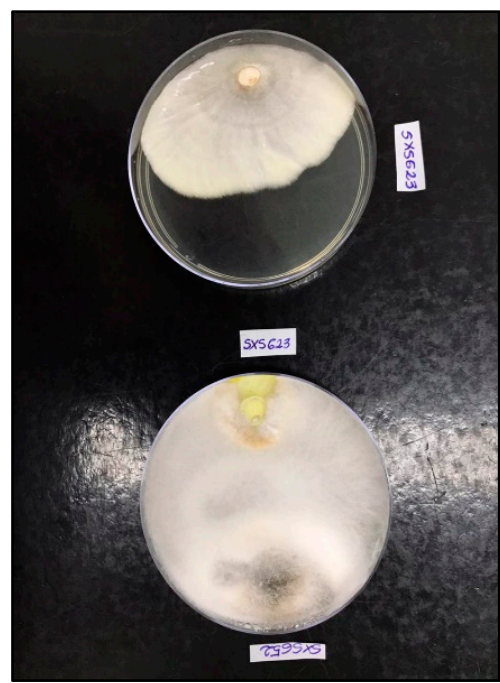

(A)

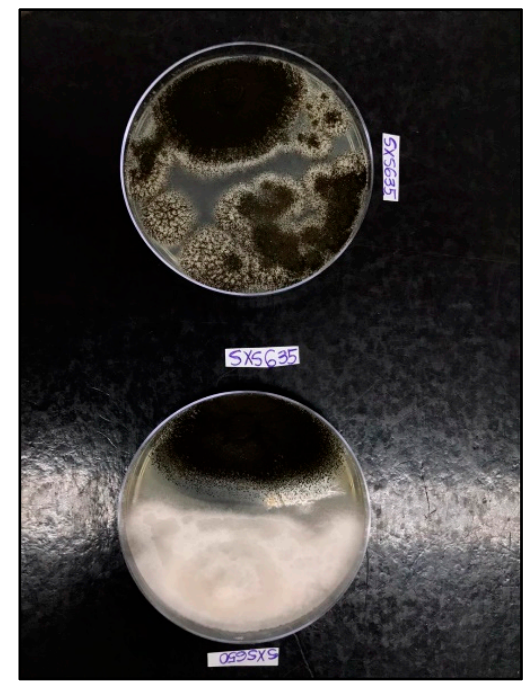

(B)

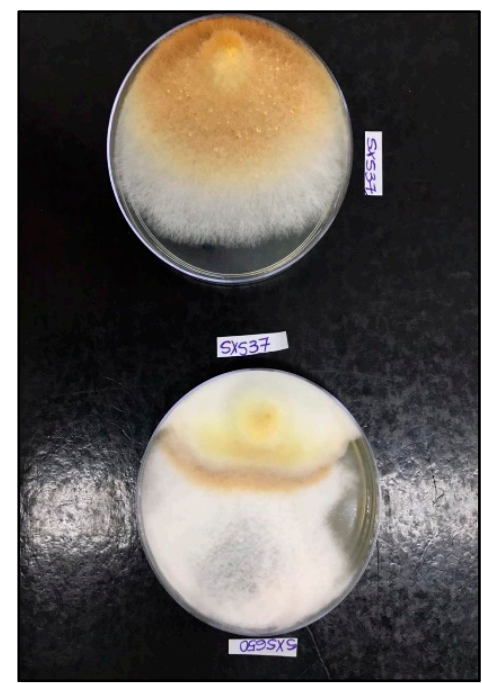

(C)

Figure 5. Paired culture test of endophytic fungi isolated from $P$. rigida Kunth against phytopathogenic fungi at 14 days of incubation. The plates arranged in the upper row correspond to the control and in the lower row to the test. (A): Above $C$. puteana SXS623 and below the same fungus $\times$ Diaporthe sp. SXS652 (PI 76.93\%). (B): Above A. niger SXS635 and below the same fungus $\times$ Pestalotiopsis sp. SXS650 (PI 59.25\%). (C): Above I. rickii SXS37 and below the same fungus $\times$ Pestalotiopsis sp. SXS650 (PI 57.14\%).

Table 6. Toxicity of extracts of endophytic fungi Colletotrichum sp. SXS649, Pestalotiopsis sp. SXS650, Botryosphaeriales SXS651, and Diaporthe sp. SXS652 isolates of $P$. rigida Kunth against $A$. salina using the Probit dose-response methodology through the Statplus program. Values correspond to the mean of the triplicates \pm standard deviation.

\begin{tabular}{cccc}
\hline Fungal Extract & $\begin{array}{c}\mathbf{C L}_{\mathbf{5 0}} \\
\left(\mathbf{m g ~ m}^{-\mathbf{1}}\right)\end{array}$ & $\begin{array}{c}\text { Break } \\
\mathbf{( 9 5 \%} \text { Confidence) }\end{array}$ & $\begin{array}{c}\text { Degree of Toxicity at All Concentrations of } \\
\text { Fungal Extract }\end{array}$ \\
\hline SXS649 & 5.00 & $4.47 \pm 5.53$ & strong \\
SXS650 & 12.51 & $10.25 \pm 14.77$ & strong \\
SXS651 & 16.46 & $15.14 \pm 17.77$ & strong \\
SXS652 & 13.23 & $10.73 \pm 15.73$ & strong \\
\hline
\end{tabular}

\section{Discussion}

The taxon Colletotrichum has been reported by several investigators as an endophyte in almost all major groups of angiosperms [60-63], and it is still characterized as an important causative pathogen of anthracnose, preharvest and postharvest fruit rots, flower dampening, and seedling burning diseases in various plant species, especially cereals, throughout the world $[64,65]$. Thus, Colletotrichum species are among the most common endophytes and pathogens in leaf structures of terrestrial plants, with a record of approximately 2200 plant species [66]. In medicinal species from the Brazilian savanna, Colletotrichum has already been endophytically isolated from Schinus terebinthifolius [67], Hancornia speciosa [68], C. sylvestris [24], and S. adstringens [22]. This is the first record of it in P. rigida.

The literature has demonstrated the presence of phenolic compounds and flavonoids in $P$. rigida. Ref. [26] verified significant levels of these phenolic compounds in a polar fraction $\left(933.25 \mu \mathrm{g} \cdot \mathrm{mL}^{-1}\right)$ of the leaves, and also the isolation of the flavonoids quercetin 3-O- $\beta-\mathrm{D}-$ glycoside, quercetin 3-O-sophoroside, and isorhamnetin 3-glycoside. In a phytochemical study of ethanol extracts from the leaves of this plant, Ref. [69] detected the presence of flavonoids at concentrations higher than standard rutin $\left(440.5\right.$ and $365.5 \mathrm{mg} \mathrm{mL}^{-1}$, respectively). Ref. [70] reported the presence of phenolic compounds in Palicourea and other species of the Rubiaceae family. The detection of these metabolites in endophytic 
fungi isolated from it confirms the similarity in production, in which host and endophytes have metabolic exchanges [71].

Notarte et al. detected the presence of phenols and flavonoids, as well as sterols and terpenoids, in Colletotrichum extracts isolated from the medicinal plant Uvaria grandiflora [72]. These compounds showed antioxidant activity with ferric reducing power $\left(4.41 \mathrm{mg} \mathrm{mL}^{-1}\right)$ and superoxide scavenging activity $\left(0.78 \mathrm{mg} \mathrm{mL}^{-1}\right)$, in addition to high toxicity against the microcrustacean $A$. salina with a lethal dose of less than $0.40 \mathrm{mg} \mathrm{mL}^{-1}$. Ref. [73] isolated three Colletotrichum species (Colletotrichum gloeosporioides, Colletotrichum tropicale, and Colletotrichum siamense) from the medicinal plant Justicia gendarussa. They showed lower and moderate antioxidant activity with the DPPH elimination method and strong cytotoxic activity and lethality to A. salina, suggesting that the extracts have bioactive metabolites, which have been identified as flavonoids, coumarins, terpenoids, and steroids. In the Brazilian savanna, secondary metabolites of Colletotrichum crassipes isolated from the leaves of the medicinal plant $C$. sylvestris exhibited potent antifungal activity against the phytopathogenic fungi Cladosporium cladosporioides and Cladosporium sphaerospermum [24].

The genus Pestalotiopsis has also been reported as endophytic of the medicinal plant Baccharis trimera from the savanna, demonstrating antifungal activity against Paracoccidioides brasiliensis [23]. Fungi of the order Botryosphaeriales have also been reported in the global literature as endophytic, living in plant tissues for long periods. However, other species of the order are phytopathogens and some cause opportunistic infections in humans [74-76] isolated 52 endophytes of the order Botryosphaeriales from Distylium chinense, which showed significant antioxidant activity and antimicrobial activity against at least one of the microorganisms evaluated by the authors. Diaporthe sp., isolated from the leaves of the medicinal plants Vernonia polyanthes and Anacardium othonianum from the savanna, demonstrated antimicrobial activity against Leishmania amazonensis [77] and were able to solubilize phosphate [78]. Gomes et al. reported a large number of Diaporthe sp. obtained from medicinal plants in Brazil, suggesting that these plants are repositories for this genus [79]. Noriler et al. found antibacterial activity in isolates of Diaporthe sp. obtained from S. adstringens [80].

In verifying the enzymatic activity of the isolates obtained from P. rigida, Colletotrichum sp. showed the highest enzyme production of amylase, cellulase, protease, and tannase, followed by Pestalotiopsis sp. and the order Botryosphaeriales, with the production of amylase and cellulase. These enzymes could be used in industry. In verifying the antioxidant activity, all isolates showed lower and moderate levels, especially Pestalotiopsis sp., which had an IC50 of $47.06 \mathrm{mg} \mathrm{mL}^{-1}$ with the FRAP method. Two isolates, Botryosphaeriales and Diaporthe sp., showed antimicrobial activity against S. epidermidis, P. aeruginosa, and E. coli, making them candidates for therapeutic use. In the verification of antitumor activity in potato discs, Colletotrichum sp. showed inhibition of tumors in $69 \%$, a result that confirmed that this isolate exhibit an antitumor bioactivity. Ref. [81] also verified that Colletotrichum sp., obtained from the leaves of Artocarpus heterophyllus, can be promising antitumor agents.

In addition, all isolates showed bioremediative activity in soil contaminated with soybean oil, with rates above $20 \%$ in the reduction in phytotoxicity. There was an increase in rates of germination and the length of roots and hypocotyls of L. sativa; the enzymes produced by the microorganisms underwent activation of the catalytic site in the presence of hydrophobic substrates, aiding in this activity [82]. Bibi et al. demonstrated that endophytic fungi obtained from healthy plants near the university campus in Mardan, Pakistan, promoted the bioremediation of chromium-contaminated soil by assay of $L$. sativa [53]. Russell et al. demonstrated the bioremediative potential of endophytic isolates of the Pestalotiopsis genus, which showed the ability to degrade the synthetic polyester polyurethane polymer [83].

Antagonistic tests against $A$. niger, I. rickii, P. mangiferae, and C. puteana had the following results: in $55 \%$ of the tests, the endophytic fungi blocked mycelial contact with the phytopathogenic fungi, in $25 \%$ they presented distance blocking to the phytopathogenic fungi, and in $20 \%$ they showed mycelial contact and partial growth on the phytopathogenic 
fungi. This interaction between endophyte and phytopathogen was marked by accelerated mycelial growth. Similar to the Colletotrichum sp. of our study, Ref. [84] found that Xylaria regalis, isolated from Thuja plicata, inhibited the phytopathogenic fungus $A$. niger. The brown rot fungus $C$. puteana, which causes a wood mass loss of up to $70 \%$ [85], was significantly inhibited by Diaporthe sp., indicating that this endophyte can be an efficient antagonist of $C$. puteana in the field. The verification of the toxicity of the isolates indicated a high lethality to the microcrustacean $A$. salina, with an LC50 of less than $100 \mathrm{mg} \mathrm{mL}^{-1}$. This indicates that caution is needed in using it for biotechnological procedures and that new tests verifying the toxic levels are necessary. However, its environmental uses are quite favorable, either for soil bioremediation or for the biological control of phytopathogens.

\section{Conclusions}

Fungi isolated from P. rigida (Colletotrichum sp. SXS649, Pestalotiopsis sp. SXS650, Botryosphaeriales SXS651 and Diaporthe sp. SXS652, native to the Brazilian savanna, proved to be producers of phenols and flavonoids in addition to amylases, cellulases, proteases, and tannases. Furthermore, they presented antioxidant, antimicrobial activity against $S$. epidermidis, P. aeruginosa and E. coli, 69\% antitumor activity in potatoes, bioremediative activity in soil with soybean oil, and antagonistic action toward the phytopathogenic fungi A. niger, I. rickii, P. mangiferae, and C. puteana. All of the fungal extracts promote a high lethality rate in $A$. salina. These data indicate that these fungi present biological activity of biotechnological interest, encouraging their applicability in soil bioremediation processes, in the control of phytopathogens, however, further investigations for therapeutic applications are necessary.

Author Contributions: Conceptualization, A.M.A.-A., M.T.M., L.L.B. and S.X.-S.; methodology, I.R.d.S., D.H.S., L.L.d.S., C.d.S.C., D.D.C.C., J.D.P.B. and M.P.; software, I.R.d.S., L.L.d.S., C.d.S.C., J.D.P.B. and L.L.B.; validation, L.L.d.S., H.A.S., M.P., D.D.C.C. and J.D.P.B.; formal analysis, I.R.d.S., L.L.d.S., C.d.S.C. and M.P.; investigation, M.T.M., M.P., D.H.S., A.M.A.-A. and L.L.B.; resources, H.A.S.; data curation, I.R.d.S., L.L.d.S., C.d.S.C. and J.D.P.B.; writing-original draft preparation, I.R.d.S., M.P., A.M.A.-A., M.T.M., D.H.S., A.M.A.-A. and S.X.-S.; writing-review and editing, I.R.d.S., A.M.A.-A., M.T.M., M.P., D.H.S., L.L.d.S., C.d.S.C., D.D.C.C., J.D.P.B., H.A.S., L.L.B. and S.X.-S.; visualization, M.T.M., A.M.A.-A., M.P., D.D.C.C., D.H.S. and S.X.-S.; supervision, A.M.A.-A., A.M.A.-A., M.T.M. and D.H.S. deposition of samples in SCUF and confirmation of enzymatic analyses and antioxidants, A.M.A.-A., H.A.S. and S.X.-S.; funding acquisition, H.A.S. All authors have read and agreed to the published version of the manuscript.

Funding: This research received no external funding.

Institutional Review Board Statement: Not applicable.

Informed Consent Statement: Not applicable.

Acknowledgments: We appreciate and thank Taif University for the financial support for Taif University Researchers Supporting Project (TURSP-2020/07), Taif University, Taif, Saudi Arabia. The authors thank the Coordenação de Aperfeiçoamento de Pessoal de Nível Superior (CAPES) and the State University of Goiás for the scholarships granted. The authors thank the curator of SCUF, Hebatallah H. Abo Nahas for her kind support and help during the preparation of this work.

Conflicts of Interest: The authors declare no conflict of interest.

\section{References}

1. Coelho, A.J.P.; Magnago, L.F.S.; Matos, F.A.R.; Mota, N.M.; Diniz, É.S.; Meira-Neto, J.A.A. Effects of Anthropogenic Disturbances on Biodiversity and Biomass Stock of Cerrado, the Brazilian Savanna. Biodivers. Conserv. 2020, 29, 3151-3168. [CrossRef]

2. Mittermeier, R.; Fonseca, G.D.; Rylands, A.B.; Brandon, K. A Brief History of Biodiversity Conservation in Brazil. Conserv. Biol. 2005, 19, 601-607. [CrossRef]

3. Mussi-Dias, V.; Araújo, A.C.O.; Silveira, S.F.; Rocabado, J.M.A.; Araújo, K.L. Fungos Endofíticos Associados a Plantas Medicinais. Rev. Bras. Plantas Med. 2012, 14, 261-266. [CrossRef] 
4. Da Silva, L.E.; Confortin, C.; Swamy, M.K. Antibacterial and Antifungal Plant Metabolites from the Tropical Medicinal Plants. In Bioactive Natural Products for Pharmaceutical Applications; Pal, D., Nayak, A.K., Eds.; Springer International Publishing: Cham, Switzerland, 2021; Volume 140, pp. 263-285. ISBN 978-3-030-54026-5.

5. Newman, D.J.; Cragg, G.M. Natural Products as Sources of New Drugs over the 30 Years from 1981 to 2010. J. Nat. Prod. 2012, 75, 311-335. [CrossRef]

6. Rajamanikyam, M.; Vadlapudi, V.; Amanchy, R.; Upadhyayula, S.M. Endophytic Fungi as Novel Resources of Natural Therapeutics. Braz. Arch. Biol. Technol. 2017, 60, 1-26. [CrossRef]

7. Sun, X.; Guo, L.-D. Endophytic Fungal Diversity: Review of Traditional and Molecular Techniques. Mycology 2012, 3, 65-76.

8. Vasundhara, M.; Reddy, M.S.; Kumar, A. Secondary Metabolites from Endophytic Fungi and Their Biological Activities. In New and Future Developments in Microbial Biotechnology and Bioengineering; Elsevier: Amsterdam, The Netherlands, 2019; pp. 237-258, ISBN 978-0-444-63504-4.

9. Gupta, S.; Chaturvedi, P.; Kulkarni, M.G.; Van Staden, J. A Critical Review on Exploiting the Pharmaceutical Potential of Plant Endophytic Fungi. Biotechnol. Adv. 2020, 39, 107462. [CrossRef]

10. Stierle, A.; Strobel, G.; Stierle, D. Taxol and Taxane Production by Taxomyces andreanae, an Endophytic Fungus of Pacific Yew. Science 1993, 260, 214-216. [CrossRef] [PubMed]

11. Zheng, R.; Li, S.; Zhang, X.; Zhao, C. Biological Activities of Some New Secondary Metabolites Isolated from Endophytic Fungi: A Review Study. Int. J. Mol. Sci. 2021, 22, 959. [CrossRef] [PubMed]

12. Mohana Kumara, P.; Zuehlke, S.; Priti, V.; Ramesha, B.T.; Shweta, S.; Ravikanth, G.; Vasudeva, R.; Santhoshkumar, T.R.; Spiteller, M.; Uma Shaanker, R. Fusarium proliferatum, an Endophytic Fungus from Dysoxylum binectariferum Hook.f, Produces Rohitukine, a Chromane Alkaloid Possessing Anti-Cancer Activity. Antonie Van Leeuwenhoek 2012, 101, 323-329. [CrossRef]

13. Chutulo, E.C.; Chalannavar, R.K. Antimicrobial Activity of Fusarium oxysporium, Endophytic Fungus, Isolated from Psidium guajava L. (White Fruit). Int. J. Pharm. Sci. Res. 2020, 11, 5844-5855.

14. Phongpaichit, S.; Rungjindamai, N.; Rukachaisirikul, V.; Sakayaroj, J. Antimicrobial Activity in Cultures of Endophytic Fungi Isolated from Garcinia species. FEMS Immunol. Med. Microbiol. 2006, 48, 367-372. [CrossRef]

15. Chen, L.; Zhang, Q.-Y.; Jia, M.; Ming, Q.-L.; Yue, W.; Rahman, K.; Qin, L.-P.; Han, T. Endophytic Fungi with Antitumor Activities: Their Occurrence and Anticancer Compounds. Crit. Rev. Microbiol. 2016, 42, 454-473. [CrossRef]

16. Cui, J.; Guo, S.; Xiao, P. Antitumor and Antimicrobial Activities of Endophytic Fungi from Medicinal Parts of Aquilaria sinensis. J. Zhejiang Univ. Sci. B 2011, 12, 385-392. [CrossRef]

17. Bhagobaty, R.K.; Joshi, S.R. Enzymatic Activity of Fungi Endophytic on Five Medicinal Plant Species of the Pristine Sacred Forests of Meghalaya, India. Biotechnol. Bioprocess Eng. 2012, 17, 33-40. [CrossRef]

18. Huang, W.-Y.; Cai, Y.-Z.; Xing, J.; Corke, H.; Sun, M. A Potential Antioxidant Resource: Endophytic Fungi from Medicinal Plants. Econ. Bot. 2007, 61, 14-30. [CrossRef]

19. Nuraini, F.R.; Setyaningsih, R.; Susilowati, A. Antioxidant Activity of Bioactive Compound Produced by Endophytic Fungi Isolated from Endemic Plant of South Kalimantan Mangifera casturi Kosterm. In AIP Conference Proceedings; AIP Publishing LLC: Melville, NY, USA, 2019; p. 080013.

20. Hu, M.Y.; Zhong, G.H.; Sun, Z.T.; Sh, G.; Liu, H.M.; Liu, X.Q. Insecticidal Activities of Secondary Metabolites of Endophytic Pencillium sp. in Derris elliptica Benth. J. Appl. Entomol. 2005, 129, 413-417. [CrossRef]

21. Rosa, L.; Tabanca, N.; Techen, N.; Wedge, D.; Bernier, U.; Becnel, J.; Elejalde, N.; Moraes, R. Antifungal and Insecticidal Activity of Endophytic Fungi Associated with the American Medicinal Plant Echinacea purpurea (L.) Moench. (Asteraceae). Planta Med. 2011, 77, 1105-1114. [CrossRef]

22. Carvalho, C.R.; Gonçalves, V.N.; Pereira, C.B.; Johann, S.; Galliza, I.V.; Alves, T.M.A.; Rabello, A.; Sobral, M.E.G.; Zani, C.L.; Rosa, C.A.; et al. The Diversity, Antimicrobial and Anticancer Activity of Endophytic Fungi Associated with the Medicinal Plant Stryphnodendron adstringens (Mart.) Coville (Fabaceae) from the Brazilian Savannah. Symbiosis 2012, 57, 95-107. [CrossRef]

23. Vieira, M.L.A.; Johann, S.; Hughes, F.M.; Rosa, C.A.; Rosa, L.H. The Diversity and Antimicrobial Activity of Endophytic Fungi Associated with Medicinal Plant Baccharis trimera (Asteraceae) from the Brazilian Savannah. Can. J. Microbiol. 2014, 60, 847-856. [CrossRef]

24. Chapla, V.; Zeraik, M.; Cafeu, M.; Silva, G.; Cavalheiro, A.; Bolzani, V.; Young, M.; Pfenning, L.; Araujo, A. Griseofulvin, Diketopiperazines and Cytochalasins from Endophytic Fungi Colletotrichum crassipes and Xylaria sp., and Their Antifungal, Antioxidant and Anticholinesterase Activities. J. Braz. Chem. Soc. 2018, 29, 1707-1713. [CrossRef]

25. Moraes, M.A.; Santos, B.C.S.; Fabri, R.L.; Scio, E.; Alves, M.S.; Yamamoto, C.H.; Rodarte, M.P.; Del-Vechio-Vieira, G.; Araújo, A.L.; de Sousa, O.V.; et al. Pharmacological Potential of Palicourea rigida Kunth: A Possible Participation of Flavonoid Compounds. J. Med. Plants Res. 2017, 11, 194-206. [CrossRef]

26. Da Rosa, E.A.; Silva, B.C.; da Silva, F.M.; Tanaka, C.M.A.; Peralta, R.M.; de Oliveira, C.M.A.; Kato, L.; Ferreira, H.D.; da Silva, C.C. Flavonoides e Atividade Antioxidante Em Palicourea rigida Kunth, Rubiaceae. Rev. Bras. Farmacogn. 2010, 20, 484-488. [CrossRef]

27. Pinheiro, R.P.; Moraes, M.A.; Santos, B.C.S.; Fabri, R.L.; Del-Vechio-Vieira, G.; Yamamoto, C.H.; Araújo, A.L.S.M.; Araújo, A.L.A.; Sousa, O.V. Identification of Compounds from Palicourea rigida Leaves with Topical Anti-Inflammatory Potential Using Experimental Models. Inflammopharmacology 2018, 26, 1005-1016. [CrossRef] [PubMed]

28. Barreto, N.M., Jr.; Angelini, R. Mapeamento Topográfico e Delimitação Fitofisionômica Da Área Natural Do Campus Da UEG (Anápolis) Mostra de Iniciação Científica da Universidade Estadual de Goiás; UEG: Anápolis, Brazil, 2003. 
29. Cardoso, M.R.D.; Marcuzzo, F.F.N.; Barros, J.R. Classificação Climática de Köppen-Geiger Para o Estado de Goiás e o Distrito Federal | Cardoso I ACTA GEOGRÁFICA. Acta Geográfica 2014, 8, 40-55.

30. Rosa, L.H.; Gonçalves, V.N.; Caligiorne, R.B.; Alves, T.M.A.; Rabello, A.; Sales, P.A.; Romanha, A.J.; Sobral, M.E.G.; Rosa, C.A.; Zani, C.L. Leishmanicidal, Trypanocidal, and Cytotoxic Activities of Endophytic Fungi Associated with Bioactive Plants in Brazil. Braz. J. Microbiol. 2010, 41, 420-430. [CrossRef] [PubMed]

31. Sutton, B.C. The Genus Glomerella and Its Anamorph Colletotrichum. In Colletotrichum: Biology, Pathology and Control; Bailey, J.A., Jeger, M.J., Eds.; CAB International: Wallingford, UK, 1992; pp. 1-26.

32. Michereff, S.I.; Noronha, M.A.; Rocha Júnior, O.M.; Silva, J.A.; Mizubuti, E.S.G. Variabilidade de isolados de Alternaria brassicicola no Estado de Pernambuco. Fitopatol. Bras. 2003, 28, 656-663. [CrossRef]

33. Udayanga, D.; Liu, X.Z.; Crous, P.W.; McKenzie, E.H.C.; Chukeatirote, E.; Hyde, K.D. A multilocus phylogenetic evaluation of Diaporthe (Phomopsis). Fungal Divers. 2012, 5, 157-171. [CrossRef]

34. Udayanga, D.; Castlebury, L.A.; Rossman, A.Y.; Hyde, K.D. Species limits in Diaporthe: Molecular re-assessment of D. citri, D. cytosporella, D. foeniculina and D. rudis. Persoonia 2014, 32, 83-101. [CrossRef]

35. Raynor, R.W. A Mycological Colour Chart; Commonwealth Mycological Institute: Surrey, England, 1970.

36. Castellani, A. The Viability of Some Pathogenic Fungi in Sterile Distilled Water. J. Trop. Med. Hyg. 1939, 24, $270-276$.

37. Bagheri, A.A.; Saadatmand, S.; Niknam, V.; Nejadsatari, T.; Babaeizad, V. Effect of Endophytic Fungus, Piriformospora indica, on Growth and Activity of Antioxidant Enzymes of Rice (Oryza sativa L.) Under Salinity Stress. Int. J. Adv. Biol. Biomed. Res. 2013, 1, 1337-1350.

38. Aly, A.H.; Debbab, A.; Kjer, J.; Proksch, P. Fungal Endophytes from Higher Plants: A Prolific Source of Phytochemicals and Other Bioactive Natural Products. Fungal Divers. 2010, 41, 1-16. [CrossRef]

39. Devi, N.N.; Prabakaran, J.J.; Wahab, F. Phytochemical Analysis and Enzyme Analysis of Endophytic Fungi from Centella asiatica. Asian Pac. J. Trop. Biomed. 2012, 2, S1280-S1284. [CrossRef]

40. Ikram, M.; Ali, N.; Jan, G.; Hamayun, M.; Jan, F.G.; Iqbal, A. Novel Antimicrobial and Antioxidative Activity by Endophytic Penicillium roqueforti and Trichoderma reesei Isolated from Solanum surattense. Acta Physiol. Plant. 2019, 41, 164. [CrossRef]

41. Singleton, V.L.; Rossi, J.A. Colorimetry of Total Phenolics with Phosphomolybdic-Phosphotungstic Acid Reagents. Am. J. Enol. Vitic. 1965, 16, 144-158.

42. Rolim, A.; Oishi, T.; Maciel, C.P.M.; Zague, V.; Pinto, C.A.S.O.; Kaneko, T.M.; Consiglieri, V.O.; Velasco, M.V.R. Total Flavonoids Quantification from O/W Emulsion with Extract of Brazilian Plants. Int. J. Pharm. 2006, 308, 107-114. [CrossRef]

43. Pontecorvo, G.; Roper, J.A.; Chemmons, L.M.; Macdonald, K.D.; Bufton, A.W.J. The Genetics of Aspergillus nidulans. In Advances in Genetics; Elsevier: Amsterdam, The Netherlands, 1953; Volume 5, pp. 141-238. ISBN 978-0-12-017605-2.

44. Hankin, L.; Anagnostakis, S.L. The Use of Solid Media for Detection of Enzyme Production by Fungi. Mycologia 1975, 67, 597. [CrossRef]

45. Florencio, C.; Couri, S.; Farinas, C.S. Correlation between Agar Plate Screening and Solid-State Fermentation for the Prediction of Cellulase Production by Trichoderma strains. Enzyme Res. 2012, 2012, e793708. [CrossRef]

46. Zhao, J.; Fu, Y.; Luo, M.; Zu, Y.; Wang, W.; Zhao, C.; Gu, C. Endophytic Fungi from Pigeon pea [Cajanus Cajan (L.) Millsp.] Produce Antioxidant Cajaninstilbene Acid. J. Agric. Food Chem. 2012, 60, 4314-4319. [CrossRef]

47. Pan, F.; Su, T.-J.; Cai, S.-M.; Wu, W. Fungal Endophyte-Derived Fritillaria unibracteata Var. wabuensis: Diversity, Antioxidant Capacities in Vitro and Relations to Phenolic, Flavonoid or Saponin Compounds. Sci. Rep. 2017, 7, 42008. [CrossRef] [PubMed]

48. Pulido, R.; Bravo, L.; Saura-Calixto, F. Antioxidant Activity of Dietary Polyphenols As Determined by a Modified Ferric Reducing/Antioxidant Power Assay. J. Agric. Food Chem. 2000, 48, 3396-3402. [CrossRef]

49. CLSI. Methods for Dilution Antimicrobial Susceptibility Tests for Bacteria That Grow Aerobically; Approved St Andard, 8th ed.; CLSI Document M07-A8; Clinical and Laboratory Standards Institute: Wayne, PA, USA, 2009.

50. Lennette, E.H.; American Society for Microbiology (Eds.) Manual of Clinical Microbiology, 4th ed.; American Society for Microbiology: Washington, DC, USA, 1985; ISBN 978-0-914826-65-1.

51. Henríquez, M.; Vergara, K.; Norambuena, J.; Beiza, A.; Maza, F.; Ubilla, P.; Araya, I.; Chávez, R.; San-Martín, A.; Darias, J.; et al Diversity of Cultivable Fungi Associated with Antarctic Marine Sponges and Screening for Their Antimicrobial, Antitumoral and Antioxidant Potential. World J. Microbiol. Biotechnol. 2014, 30, 65-76. [CrossRef]

52. Trigui, F.; Pigeon, P.; Jalleli, K.; Top, S.; Aifa, S.; El Arbi, M. Selection of a Suitable Disc Bioassay for the Screening of Anti-Tumor Molecules. Int. J. Biomed. Sci. 2013, 9, 230-236.

53. Bibi, S.; Hussain, A.; Hamayun, M.; Rahman, H.; Iqbal, A.; Shah, M.; Irshad, M.; Qasim, M.; Islam, B. Bioremediation of Hexavalent Chromium by Endophytic Fungi; Safe and Improved Production of Lactuca sativa L. Chemosphere 2018, 211, 653-663. [CrossRef]

54. Mariano, R.L.R. Métodos de Seleção in Vitro Para o Controle Microbiológico de Patógenos de Plantas. Revisão Anu. Patol. Plantas 1993, 1, 369-409.

55. Badalyan, S.M.; Garibyan, N.G.; Innocenti, G. Antagonistic Activity of Xylotrophic mushrooms against Pathogenic Fungi of Cereals in Dual Culture; Firenze University Press: Adelaide, Australia, 2002; Volume 41, pp. 220-225.

56. Edgington, L.V.; Knew, K.L.; Barron, G.L. Fungitoxic Spectrum of Benzimidazole Compounds. Phytopathology 1971, 61, 42. [CrossRef] 
57. Molina-Salinas, G.; Said-Fernández, S.; Nuevo, M. A Modified Microplate Cytotoxicity Assay with Brine Shrimp Larvae (Artemia salina). Pharmacologyonline 2006, 3, 633-638.

58. Svensson, B.-M.; Mathiasson, L.; Mårtensson, L.; Bergström, S. Artemia salina as Test Organism for Assessment of Acute Toxicity of Leachate Water from Landfills. Environ. Monit. Assess. 2005, 102, 309-321. [CrossRef]

59. Nguta, J.; Mbaria, J.; Gakuya, D.; Gathumbi, P.K.; Kabasa, J.; Kiama, S. Biological Screening of Kenyan Medicinal Plants Using Artemia salina L. (ARTEMIIDAE). Pharmacologyonline 2011, 2, 458-478.

60. Dame, Z.T.; Silima, B.; Gryzenhout, M.; van Ree, T. Bioactive Compounds from the Endophytic Fungus Fusarium proliferatum. Nat. Prod. Res. 2016, 30, 1301-1304. [CrossRef]

61. Hofstetter, V.; Buyck, B.; Croll, D.; Viret, O.; Couloux, A.; Gindro, K. What If Esca Disease of Grapevine Were Not a Fungal Disease? Fungal Divers. 2012, 54, 51-67. [CrossRef]

62. Rivera-Orduña, F.N.; Suarez-Sanchez, R.A.; Flores-Bustamante, Z.R.; Gracida-Rodriguez, J.N.; Flores-Cotera, L.B. Diversity of Endophytic Fungi of Taxus globosa (Mexican Yew). Fungal Divers. 2011, 47, 65-74. [CrossRef]

63. Tadych, M.; Bergen, M.S.; Johnson-Cicalese, J.; Polashock, J.J.; Vorsa, N.; White, J.F. Endophytic and Pathogenic Fungi of Developing Cranberry Ovaries from Flower to Mature Fruit: Diversity and Succession. Fungal Divers. 2012, 54, 101-116. [CrossRef]

64. Bailey, J.A.; Jeger, M.J. Colletotrichum: Biology, Pathology and Control; CAB International Press: Wallingford, UK, 1992.

65. Manamgoda, D.S.; Udayanga, D.; Cai, L.; Chukeatirote, E.; Hyde, K.D. Endophytic Colletotrichum from Tropical Grasses with a New Species C. endophytica. Fungal Divers. 2013, 61, 107-115. [CrossRef]

66. Farr, D.F.; Rossman, A.Y. Fungal Databases, U.S. National Fungus Collections, ARS, USDA. Available online: https://nt.ars-grin. gov / fungaldatabases/ (accessed on 12 July 2021).

67. Tonial, F.; Maia, B.H.L.N.S.; Gomes-Figueiredo, J.A.; Sobottka, A.M.; Bertol, C.D.; Nepel, A.; Savi, D.C.; Vicente, V.A.; Gomes, R.R.; Glienke, C. Influence of Culturing Conditions on Bioprospecting and the Antimicrobial Potential of Endophytic Fungi from Schinus terebinthifolius. Curr. Microbiol. 2016, 72, 173-183. [CrossRef] [PubMed]

68. Chagas, M.B.D.O.; Dos Santos, I.P.; Da Silva, L.C.N.; Correia, M.T.D.S.; De Araújo, J.M.; Cavalcanti, M.D.S.; Lima, V. Antimicrobial Activity of Cultivable Endophytic Fungi Associated with Hancornia speciosa Gomes Bark. Open Microbiol. J. 2017, 11, 179-188. [CrossRef] [PubMed]

69. Lima Neto, G.A.; Kaffashi, S.; Luiz, W.T.; Ferreira, W.R.; Dias Da Silva, Y.S.A.; Pazin, G.V.; Violante, I.M.P. Quantificação de Metabólitos Secundários e Avaliação Da Atividade Antimicrobiana e Antioxidante de Algumas Plantas Selecionadas Do Cerrado de Mato Grosso. Rev. Bras. Plantas Med. 2015, 17, 1069-1077. [CrossRef]

70. Machado, A.D.O.; Silva, A.P.; Consolaro, H.; Barros, M.A.G.; Oliveira, P.E. Breeding Biology and Distyly in Palicourea rigida H. B. \& K. (Rubiaceae) in the Cerrados of Central Brazil. Acta Bot. Bras. 2010, 24, 686-696. [CrossRef]

71. Jia, M.; Chen, L.; Xin, H.-L.; Zheng, C.-J.; Rahman, K.; Han, T.; Qin, L.-P. A Friendly Relationship between Endophytic Fungi and Medicinal Plants: A Systematic Review. Front. Microbiol. 2016, 7, 906. [CrossRef] [PubMed]

72. Notarte, K.I.R.; Devanadera, M.K.P.; Mayor, A.B.R.; Cada, M.C.A.; Pecundo, M.H.; Macabeo, A.P.G. Toxicity, Antibacterial, and Antioxidant Activities of Fungal Endophytes Colletotrichum and Nigrospora spp. Isolated from Uvaria grandiflora. Philipp. J. Sci. 2019, 148, 503-510.

73. Mahmud, S.M.N.; Sohrab, M.H.; Begum, M.N.; Rony, S.R.; Sharmin, S.; Moni, F.; Akhter, S.; Mohiuddin, A.K.M.; Afroz, F. Cytotoxicity, Antioxidant, Antimicrobial Studies and Phytochemical Screening of Endophytic Fungi Isolated from Justicia gendarussa. Ann. Agric. Sci. 2020, 65, 225-232. [CrossRef]

74. Slippers, B.; Boissin, E.; Phillips, A.J.L.; Groenewald, J.Z.; Lombard, L.; Wingfield, M.J.; Postma, A.; Burgess, T.; Crous, P.W. Phylogenetic Lineages in the Botryosphaeriales: A Systematic and Evolutionary Framework. Stud. Mycol. 2013, 76, 31-49. [CrossRef] [PubMed]

75. Slippers, B.; Roux, J.; Wingfield, M.J.; van der Walt, F.J.J.; Jami, F.; Mehl, J.W.M.; Marais, G.J. Confronting the Constraints of Morphological Taxonomy in the Botryosphaeriales. Pers. Mol. Phylogeny Evol. Fungi 2014, 33, 155-168. [CrossRef]

76. Duan, X.; Xu, F.; Qin, D.; Gao, T.; Shen, W.; Zuo, S.; Yu, B.; Xu, J.; Peng, Y.; Dong, J. Diversity and Bioactivities of Fungal Endophytes from Distylium chinense, a Rare Waterlogging Tolerant Plant Endemic to the Three Gorges Reservoir. BMC Microbiol. 2019, 19, 278. [CrossRef] [PubMed]

77. Do Nascimento, A.M.; Soares, M.G.; da Silva Torchelsen, F.K.V.; de Araujo, J.A.V.; Lage, P.S.; Duarte, M.C.; Andrade, P.H.R.; Ribeiro, T.G.; Coelho, E.A.F.; do Nascimento, A.M. Antileishmanial Activity of Compounds Produced by Endophytic Fungi Derived from Medicinal Plant Vernonia polyanthes and Their Potential as Source of Bioactive Substances. World J. Microbiol. Biotechnol. 2015, 31, 1793-1800. [CrossRef]

78. Faria, P.C.S.; Senabio, J.; Soares, M.; Silva, F.G.; Cunha, A.P.; Souchie, E.L. Assessment of Functional Traits in the Assemblage of Endophytic Fungi of Anacardium othonianum Rizzini. Pak. J. Bot. 2016, 48, 1241-1252.

79. Gomes, R.R.; Glienke, C.; Videira, S.I.R.; Lombard, L.; Groenewald, J.Z.; Crous, P.W. Diaporthe: A Genus of Endophytic, Saprobic and Plant Pathogenic Fungi. Pers. Mol. Phylogeny Evol. Fungi 2013, 31, 1-41. [CrossRef] [PubMed]

80. Noriler, S.A.; Savi, D.C.; Aluizio, R.; Palácio-Cortes, A.M.; Possiede, Y.M.; Glienke, C. Bioprospecting and Structure of Fungal Endophyte Communities Found in the Brazilian Biomes, Pantanal, and Cerrado. Front. Microbiol. 2018, 9, 1526. [CrossRef]

81. Sunkar, S.; Sibitha, V.; Nachiyar, V.; Pandurangan, P.; Renugadevi, K. Bioprospecting Endophytic Fungus Colletotrichum sp. Isolated from Artocarpus heterophyllus for Anticancer Activity. Res. J. Biotechnol. 2017, 12, 46-56. 
82. Krishnamurthy, Y.L.; Naik, B.S. Endophytic Fungi Bioremediation. In Endophytes: Crop Productivity and Protection; Maheshwari, D.K., Annapurna, K., Eds.; Springer International Publishing: Cham, Switzerland, 2017; Volume 16, pp. 47-60, ISBN 978-3-319-66543-6.

83. Russell, J.R.; Huang, J.; Anand, P.; Kucera, K.; Sandoval, A.G.; Dantzler, K.W.; Hickman, D.; Jee, J.; Kimovec, F.M.; Koppstein, D.; et al. Biodegradation of Polyester Polyurethane by Endophytic Fungi. Appl. Environ. Microbiol. 2011, 77, 6076-6084. [CrossRef]

84. Adnan, M.; Alshammari, E.; Ashraf, S.A.; Patel, K.; Lad, K.; Patel, M. Physiological and Molecular Characterization of Biosurfactant Producing Endophytic Fungi Xylaria regalis from the Cones of Thuja plicata as a Potent Plant Growth Promoter with Its Potential Application. BioMed Res. Int. 2018, 2018, 7362148. [CrossRef] [PubMed]

85. Hiltunen, S.; Mankinen, A.; Javed, M.A.; Ahola, S.; Venäläinen, M.; Telkki, V.-V. Characterization of the Decay Process of Scots Pine Caused by Coniophora puteana Using NMR and MRI. Holzforschung 2020, 74, 1021-1032. [CrossRef] 